\title{
Spectroscopic, Thermal, Fluorescence Studies and Antibacterial Activity of Some Transition Metals with Schiff Base 2-[(2- Furylmethylene) Amino] Benzoic Acid
}

\author{
Omyma Ahmed Moustafa Ali $^{\mathrm{a} *}$, Samir Moustafa EL-Medani ${ }^{\mathrm{b}}$, Abeer Sayed Salama Sayed ${ }^{\mathrm{b}}$ \\ ${ }^{a}$ Chemistry Department, Faculty of Women for Arts, Science and Education, Ain Shams University, Cairo, \\ Egypt. \\ ${ }^{b}$ Chemistry Department, Faculty of Science, El-Faiyum University, El-Faiyum, Egypt.
}

*Corresponding Author: Omyma Ahmed Moustafa Ali, Chemistry Department, Faculty of Women for Arts, Science and Education, Ain Shams University, Cairo, Egypt.

\begin{abstract}
Complexes of the Schiff base ligand (HL) derived from 2-furancarboxaldehyde and 2aminobenzoic acid with the metal ions: $\mathrm{Cu}(\mathrm{II}), \mathrm{Ni}(\mathrm{II}), \mathrm{Co}(\mathrm{II}), \mathrm{Zn}(\mathrm{II}), \mathrm{Hg}(\mathrm{II}), \mathrm{Fe}(\mathrm{III}), \mathrm{La}(\mathrm{III})$ and Sm(III) have been prepared. The ligand HL and its metal complexes were characterized on the bases of its elemental analyses, IR, ${ }^{1} H$ NMR, solid reflectance, magnetic moment, molar conductance and thermal analysis. The complexes were found to have the formulae $\left[\mathrm{Cu}(\mathrm{HL})(\mathrm{AcO})_{2}\right] \cdot \mathrm{H}_{2} \mathrm{O},\left[\mathrm{M}(\mathrm{HL})(\mathrm{AcO})_{2} \mathrm{H}_{2} \mathrm{O}\right] \cdot \mathrm{H}_{2} \mathrm{O}(\mathrm{M}=\mathrm{Ni}, \mathrm{Co}, \mathrm{Zn}$ and $\mathrm{Hg}), \quad\left[\mathrm{Fe}(\mathrm{HL}) \mathrm{Cl}_{3}\right] . \mathrm{H}_{2} \mathrm{O}, \quad\left[\mathrm{La}(\mathrm{HL})\left(\mathrm{NO}_{3}\right)_{3}\right] \cdot 2 \mathrm{H}_{2} \mathrm{O}$ and $\left[\mathrm{Sm}(\mathrm{HL})\left(\mathrm{ClO}_{4}\right)_{3}\right] .2 \mathrm{H}_{2} \mathrm{O}$. The conductance of complexes was measured and revealed non-electrolyte chelates. Thermal analysis of the complexes were investigated and indicated the presence of hydrated water molecules. The ligand and its complexes were tested by weight loss method and found corrosion inhibition for stainless steel type 410 in $1 \mathrm{M} \mathrm{H}_{2} \mathrm{SO}_{4}$ medium. Fluorescence and antibacterial activities of the synthesized compoundswere investigated indicating photoactive materials and a considerable biological activity.
\end{abstract}

Keywords: Complexes; Spectral; Fluorescence; Corrosion Inhibition.

\section{INTRODUCTION}

Schiff bases are considered as a very important class of organic compounds because of their ability to form stable complexes with many different transition metal ions in various oxidation states [1-10]. These complexes have wide applications in some biological aspects [11-20], catalytic activity [21-22] and fluorescence properties [23]. Several Schiff bases have recently been investigated as corrosion inhibitors for various metals and alloys in acid media [24, 25]. The inhibition of corrosion by Schiff bases can be attributed to its molecules with $\pi$-electrons of $-\mathrm{C}=\mathrm{N}$ - groups and $\boldsymbol{\pi}$-electrons of aromatic ring. Conjugating large $\mathrm{p}$ bond through which its molecules are likely to be adsorbed strongly on the metal surface. Coordination numbers of lanthanide complexes are in range from six to twelve, eight and nine being the most common coordination numbers. Lanthanides are weak Lewis acids and preferably coordinate to hard Lewis bases like oxygen. In this paper, we report synthesis of eight Schiff base complexes of $\mathrm{Cu}(\mathrm{II}), \mathrm{Ni}(\mathrm{II}), \mathrm{Co}(\mathrm{II}), \mathrm{Zn}$ (II), $\mathrm{Hg}$ (II), $\mathrm{Fe}$ (III), $\mathrm{La}$ (III) and $\mathrm{Sm}(\mathrm{III})$ metal ions. The complexes were characterized by elemental analysis, solid reflectance, FT-IR and fluorescence spectroscopy, thermal analysis and molar conductance. Also, the inhibition effects of the studied compounds on the corrosion of stainless steel 410 (SS410) in $\mathrm{H}_{2} \mathrm{SO}_{4} 1 \mathrm{M}$ solutions were investigated.

\section{Experimental}

\section{Materials AND MethodS}

All chemicals used were of analytical reagent grade (AR) and of the highest purity available. They included 2-furanecarboxaldehyde (Sigma), 2-aminobenzoic acid, $\mathrm{Cu}(\mathrm{OAc})_{2} \cdot \mathrm{H}_{2} \mathrm{O}, \mathrm{FeCl}_{3} \cdot 6 \mathrm{H}_{2} \mathrm{O}$, $\mathrm{Ni}(\mathrm{OAc})_{2} \cdot 4 \mathrm{H}_{2} \mathrm{O}, \quad \mathrm{Co}(\mathrm{OAc})_{2} \cdot 4 \mathrm{H}_{2} \mathrm{O}, \quad \mathrm{Zn}(\mathrm{OAc})_{2} \cdot 4 \mathrm{H}_{2} \mathrm{O}, \quad \mathrm{Hg}(\mathrm{OAc})_{2} \cdot 4 \mathrm{H}_{2} \mathrm{O}, \quad \mathrm{La}\left(\mathrm{NO}_{3}\right)_{3} \cdot 6 \mathrm{H}_{2} \mathrm{O}$ and $\mathrm{Sm}\left(\mathrm{ClO}_{4}\right)_{3} \cdot 6 \mathrm{H}_{2} \mathrm{O}$ from Aldrich. All solvents were of analytical grade. IR measurements (KBr pellets) were carried out on a Shimadzu 8000 FT-IR spectrometer. ${ }^{1}$ HNMR spectra were recorded on a BrukerAvance Dry 300 FT-NMR spectrometer in DMSO-d6 with TMS as the internal reference. The mass spectra were recorded on a GCMS-QP 2010 Shimadzu mass spectrometer with DI (direct inlet) 
and CI (chemical ionization). Thermo gravimetric analyses (TG and DTG) were carried out under $\mathrm{N}_{2}$ atmosphere with a heating rate of $10^{\circ} \mathrm{C} / \mathrm{min}$. using a Shimadzu DT-50 thermal analyzer. Magnetic susceptibility measurements of the paramagnetic complexes in the solid state (Gouy method) were performed on a Sherwood Scientific Magnetic Susceptibility Balance. Microanalyses were performed using JEOL JMS-AX500 elemental analyzer. All conductivity measurements were performed in DMF $\left(1 \times 10^{-3} \mathrm{M}\right)$ at $25^{\circ} \mathrm{C}$, by using Jenway 4010 conductivity meter. UV/Vis diffuse reflectance spectra were measured on a Shimadzu 3101 pc spectrophotometer. The photo luminescent properties of all compounds were studied using a Jenway 6270 Fluorimeter.

\subsection{Synthesis of Schiff Base Ligand (HL)}

A hot solution of 2-aminobenzoic acid $(14 \mathrm{mmol})$ was mixed with a hot solution of 2furancarboxaldehyde (14 mmol) in $150 \mathrm{ml}$ absolute methanol. The resulting mixture was left under reflux for $4 \mathrm{~h}$ and the solid product formed was separated by filtration, washed with methanol, and then dried in a vacuum over anhydrous calcium chloride. The yellow powder product is produced in $80 \%$ yield.

\subsection{Synthesis of Metal Complexes}

The metal complexes of the Schiff base, HL, were prepared by the addition of a hot solution of the metal acetate, chloride, nitrate or perchlorate $(1 \mathrm{mmol})$ in an ethanol $(25 \mathrm{ml})$ to the hot solution of the Schiff base $(1 \mathrm{mmol})$ in tetrahydrofurane (THF) solvent $(25 \mathrm{ml})$. The resulting mixture was stirred under reflux for $4 \mathrm{~h}$ whereupon the complexes precipitated. They were collected by filtration and washed with diethyl ether.

\subsection{Corrosion Test}

Gravimetric corrosion measurements (weight loss method) were carried out according to the ASTM standard procedure described in [26]. In brief, stainless steel specimens in triplicate were immersed for a period of $2 \mathrm{~h}$ in $100 \mathrm{ml} 1 \mathrm{M} \mathrm{H}_{2} \mathrm{SO}_{4}$ containing various concentrations of the studied inhibitors. The mass of the specimens before and after immersion was determined using an analytical balance accurate to $0.1 \mathrm{mg}$. Before measurements, the specimens were abraded with a sequence of emery papers of different grades $(400,800,1000$ and 1200), followed by washing with double distilled water and finally degreased with ethanol and dried at room temperature. The composition of the stainless steel type 410 are in wt. \% 0.15C, $11 \mathrm{Cr}, 75 \mathrm{Fe}, 1 \mathrm{Mn}, 0.75 \mathrm{Ni}, 0.04 \mathrm{P}, 0.03 \mathrm{~S}, 1 \mathrm{Si}$.

\subsection{In Vitro Antibacterial Study}

The in vitro antibacterial activity of the ligand and its complexes were screened against the bacteria Staphylococcus aureus, Bacillus subtilis, Escherichia coli and Pseudomonas aeruginosa by the paper disc method using nutrient agar as the medium. The standard disc diffusion method was followed to determine the antibacterial activity of the synthesized compounds. The well ( $8 \mathrm{~mm}$ diameter) was then filled with the test solution and the plates were inoculated at $37^{\circ} \mathrm{C}$ for $48 \mathrm{~h}$. During this period, the growth of the inoculated microorganisms was affected and then the inhibition zones developed on the plates were measured. The effectiveness of an antibacterial agent was assessed by measuring the zones of inhibition around the well. The diameter of the zone is measured to the nearest millimeter $(\mathrm{mm})$. The antibacterial activity of each compound was compared with that of standard antibiotics such as Tetracycline. DMSO was used as a control under the same conditions for each organism and no activity was found. The activity results were calculated as a mean of triplicates.

\section{RESULTS AND DISCUSSION}

In the present investigation, the Schiff base ligand (HL) and its complexes are synthesize and characterize by different analytical techniques. The isolated solid complexes are stable in air at room temperature, insoluble in water and most organic solvents and soluble in DMF and DMSO solvents. Various attempts to obtain the single crystals of the complexes have so far been unsuccessful. The analytical data along with some physical properties of Schiff base ligand and its complexes are summarized in Table 1. 
Spectroscopic, Thermal, Fluorescence Studies and Antibacterial Activity of Some Transition Metals with Schiff Base 2-[(2-Furylmethylene) Amino] Benzoic Acid

Table1. Analytical and physical data of the ligand and its complexes

\begin{tabular}{|c|c|c|c|c|c|c|c|}
\hline Compound & Color (\% yield) & \multirow{2}{*}{ M.Wt. } & \multirow{2}{*}{ M.p./ $/{ }^{\circ} \mathrm{C}$} & \multicolumn{3}{|c|}{ Found(Calculated) } & $\Lambda_{\mathrm{m}}\left(\Omega^{-1} \mathrm{~mol}^{-}\right.$ \\
\cline { 5 - 7 } & & & & $\% \mathrm{C}$ & $\% \mathrm{H}$ & $\% \mathrm{~N}$ & $\left.\mathrm{~cm}^{2}\right)$ \\
\hline $\mathrm{HL}\left(\mathrm{C}_{12} \mathrm{H}_{9} \mathrm{NO}_{3}\right)$ & Yellow(80) & 215.21 & 180 & $66.78(66.97)$ & $4.34(4.21)$ & $6.63(6.51)$ & - \\
\hline $\mathrm{CuC}_{16} \mathrm{H}_{17} \mathrm{NO}_{8}$ & Dark brown(70) & 414.85 & $>300$ & $46.65(46.32)$ & $4.04(4.13)$ & $3.42(3.38)$ & 2.5 \\
\hline $\mathrm{NiC}_{16} \mathrm{H}_{19} \mathrm{NO}_{9}$ & Violet(60) & 428.04 & $>300$ & $44.96(44.90)$ & $4.27(4.47)$ & $3.16(3.27)$ & 1.1 \\
\hline $\mathrm{FeC}_{12} \mathrm{H}_{11} \mathrm{NO}_{4} \mathrm{Cl}_{3}$ & Black (80) & 395.43 & $>300$ & $36.10(36.45)$ & $2.47(2.80)$ & $3.65(3.54)$ & 2.9 \\
\hline $\mathrm{CoC}_{16} \mathrm{H}_{19} \mathrm{NO}_{9}$ & Brown(60) & 428.26 & $>300$ & $44.53(44.87)$ & $4.18(4.47)$ & $3.52(3.27)$ & 1.7 \\
\hline $\mathrm{ZnC}_{16} \mathrm{H}_{19} \mathrm{NO}_{9}$ & Dark brown(60) & 434.70 & $>300$ & $44.15(44.21)$ & $4.59(4.41)$ & $3.69(3.22)$ & 0.01 \\
\hline $\mathrm{HgC}_{16} \mathrm{H}_{19} \mathrm{NO}_{9}$ & Yellow(70) & 569.92 & $>300$ & $33.38(33.72)$ & $3.16(3.36)$ & $2.17(2.46)$ & 1.1 \\
\hline $\mathrm{LaC}_{12} \mathrm{H}_{13} \mathrm{~N}_{4} \mathrm{O}_{14}$ & Black(70) & 576.16 & $>300$ & $25.44(25.02)$ & $2.96(2.27)$ & $9.14(9.72)$ & 3 \\
\hline $\mathrm{SmC}_{12} \mathrm{H}_{13} \mathrm{NO}_{17} \mathrm{Cl}_{3}$ & Black(80) & 699.94 & $>300$ & $20.25(20.59)$ & $1.77(1.87)$ & $2.34(2.00)$ & 2.5 \\
\hline
\end{tabular}

\subsection{Composition And Structures of HL Schiff Base Complexes}

The stoichiometries of the complexes derived from elemental analysis correspond to the general formulae $\left[\mathrm{Cu}(\mathrm{HL})(\mathrm{AcO})_{2}\right] \cdot \mathrm{H}_{2} \mathrm{O}, \quad\left[\mathrm{M}(\mathrm{HL})(\mathrm{AcO})_{2} \mathrm{H}_{2} \mathrm{O}\right] \cdot \mathrm{H}_{2} \mathrm{O} \quad(\mathrm{M}=\mathrm{Ni}, \quad \mathrm{Co}, \quad \mathrm{Zn}$ and $\mathrm{Hg})$, $\left[\mathrm{Fe}(\mathrm{HL}) \mathrm{Cl}_{3}\right] \cdot \mathrm{H}_{2} \mathrm{O},\left[\mathrm{La}(\mathrm{HL})\left(\mathrm{NO}_{3}\right)_{3}\right] \cdot 2 \mathrm{H}_{2} \mathrm{O}$ and $\left[\mathrm{Sm}(\mathrm{HL})\left(\mathrm{ClO}_{4}\right)_{3}\right] \cdot 2 \mathrm{H}_{2} \mathrm{O}$, Scheme 1. These propositions are also in accord with molar conductivity measurements, TGA, IR, UV-vis and ${ }^{1} \mathrm{H}$ NMR presented in the following sections. The formation of complexes may proceed according to the following equations given below.<smiles>CO[Ge]1(O)OC(=O)c2ccccc2N1Cc1ccco1</smiles>

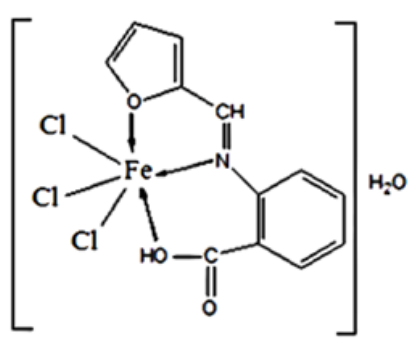

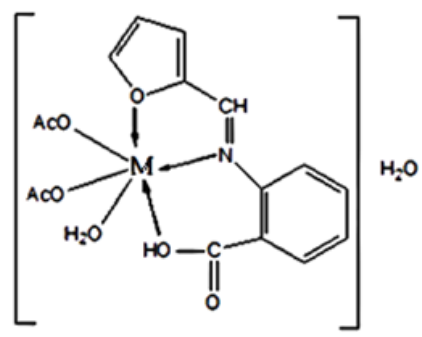<smiles>COC(=O)c1ccccc1N1OC(=O)c2ccccc2O1</smiles>

$\mathrm{M}=\mathrm{Ni}, \mathrm{Co}, \mathrm{Zn}$ and $\mathrm{Hg}$

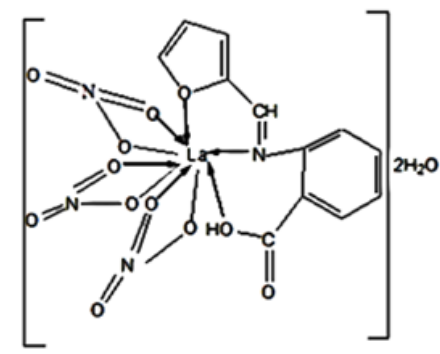

Scheme1. Structures of complexes

$\mathrm{Cu}(\mathrm{AcO})_{2}+\mathrm{HL}+\mathrm{H}_{2} \mathrm{O} \rightarrow\left[\mathrm{Cu}(\mathrm{HL})(\mathrm{AcO})_{2}\right] \cdot \mathrm{H}_{2} \mathrm{O}$

$\mathrm{M}(\mathrm{AcO})_{2}+\mathrm{HL}+2 \mathrm{H}_{2} \mathrm{O} \rightarrow\left[\mathrm{M}(\mathrm{HL})(\mathrm{AcO})_{2} \mathrm{H}_{2} \mathrm{O}\right] \cdot \mathrm{H}_{2} \mathrm{O}$

$\mathrm{M}=\mathrm{Ni}$ (II), Co (II), Zn (II) and $\mathrm{Hg}$ (II)

$\mathrm{FeCl}_{3}+\mathrm{HL}+\mathrm{H}_{2} \mathrm{O} \rightarrow[\mathrm{Fe}(\mathrm{HL}) \mathrm{Cl} 3] \cdot \mathrm{H}_{2} \mathrm{O}$

$\mathrm{MX}_{3}+\mathrm{HL}+2 \mathrm{H}_{2} \mathrm{O} \rightarrow[\mathrm{M}(\mathrm{HL}) \mathrm{X} 3] \cdot 2 \mathrm{H}_{2} \mathrm{O}$ 
Spectroscopic, Thermal, Fluorescence Studies and Antibacterial Activity of Some Transition Metals with Schiff Base 2-[(2-Furylmethylene) Amino] Benzoic Acid

$\mathrm{M}=\mathrm{La}(\mathrm{III}), \mathrm{X}=\left(\mathrm{NO}_{3}\right)$ or $\mathrm{M}=\mathrm{Sm}(\mathrm{III}), \mathrm{X}=\left(\mathrm{ClO}_{4}\right)$

\subsection{Molar Conductivity Measurements}

The chelates are dissolved in DMF and the molar conductivities of $10^{-3} \mathrm{M}$ of their solutions at $25^{\circ} \mathrm{C}$ are measured. Table 1 shows the molar conductance values of the complexes. It is concluded from the results that the complexes have a molar conductivity values in the range from 0.1 to $3.0 \Omega^{-1} \mathrm{~mol}^{-1} \mathrm{~cm}^{2}$ indicating non-ionic nature complexes (non-electrolytes).

\subsection{IR Spectra and Mode of Bonding}

The IR band assignments of the Schiff base ligand and its complexes are given in Table 2. Comparison of the IR spectra of the metal complexes with that of the free ligand revealed that all complexes showed a broad band in the range $3278-3423 \mathrm{~cm}^{-1}$ assignable to $v(\mathrm{OH})$ of the carboxylic acid group, the coordinated and hydrated water molecules. The band at $1666 \mathrm{~cm}^{-1}$ assigned to $v(\mathrm{C}=\mathrm{N})$ in the free Schiff base was shifted to lower frequency $\left(1598-1626 \mathrm{~cm}^{-1}\right)$ in all complexes indicating the participation of the azomethine nitrogen in chelation [27]. It is expected that coordination of nitrogen to the metal atom would reduce the electron density in the azomethine link and thus lowering the $\mathrm{HC}=\mathrm{N}$ bond order. The $v_{\text {asym }}\left(\mathrm{COO}^{-}\right)$and $v_{\text {sym }}\left(\mathrm{COO}^{-}\right)$stretching vibrations are observed at 1579 and $1413 \mathrm{~cm}^{-1}$ for HL ligand [28]. On complexation, these bands were shifted to 1515-1592 and $1333-1407 \mathrm{~cm}^{-1}$, respectively. A medium intensity band due to $v(\mathrm{C}-\mathrm{O}-\mathrm{C})$ stretching vibration of furan appeared at $1255 \mathrm{~cm}^{-1}$ in the ligand. This band was shifted to $1223-1288 \mathrm{~cm}^{-1}$ in complexes, suggesting coordination through oxygen of furan moiety [23]. Non-ligand IR bands were displayed in the complexes. The triply split band maxima at $1145,1115,1087 \mathrm{~cm}^{-1}$ and a medium band at $628 \mathrm{~cm}^{-}$ ${ }^{1}$ appeared in Sm(III) complex spectrum were attributed to bidentately coordinated perchlorate anion $[29,30]$. The IR spectrum of the La(III) complex showed four intense bands at 1456, 1385, 1333 and $818 \mathrm{~cm}^{-1}$. The separation frequency of $123 \mathrm{~cm}^{-1}$ between $1456\left(v_{\mathrm{s}}\right)$ and $1333\left(v_{\mathrm{as}}\right)$ isconsistent with the value reported in literature for the nitrate group coordinated in a bidentate manner [31]. Appearance of new bands in the spectra of complexes in the regions $465-528 \mathrm{~cm}^{-1}$ and $422-470 \mathrm{~cm}^{-1}$ were assigned to $v(\mathrm{M}-\mathrm{O})$ and $v(\mathrm{M}-\mathrm{N})$ stretching vibration [32].

Table2. IR data (4000-400 $\left.\mathrm{cm}^{-1}\right)$ of the Schiff base ligand and its complexes

\begin{tabular}{|c|c|c|c|c|c|c|c|c|c|}
\hline \multirow[t]{2}{*}{ Compound } & \multicolumn{8}{|c|}{ IR data $\left(\mathrm{cm}^{-1}\right)^{\mathrm{a}}$} & \multirow[b]{2}{*}{ Other bands } \\
\hline & $\begin{array}{l}(\mathrm{OH}) \text { or } \\
(\mathrm{H} 2 \mathrm{O})\end{array}$ & $\begin{array}{c}\mathrm{COO} \\
\text { (asym) }\end{array}$ & $\begin{array}{l}\mathrm{COO} \\
(\mathrm{sym})\end{array}$ & $\mathrm{C}=\mathrm{N}$ & $\begin{array}{c}\mathrm{C}-\mathrm{O}-\mathrm{C} \\
\text { (furan) }\end{array}$ & $\begin{array}{c}\mathrm{M}-\mathrm{O} \\
\text { (carboxyli } \\
\mathrm{c})\end{array}$ & $\begin{array}{c}\mathrm{M}-\mathrm{O} \\
\text { (furan) }\end{array}$ & $\mathrm{M}-\mathrm{N}$ & \\
\hline HL & $\begin{array}{c}3318(\mathrm{~b} \\
)\end{array}$ & $1579(\mathrm{~s})$ & 1413(s) & $1666(s)$ & $1255(\mathrm{~m})$ & - & - & - & - \\
\hline$\left[\mathrm{Cu}(\mathrm{HL})(\mathrm{AcO})_{2}\right] \cdot \mathrm{H}_{2} \mathrm{O}$ & $\begin{array}{c}3278(b \\
)\end{array}$ & $1558(\mathrm{~s})$ & 1384(s) & $1604(s)$ & $1288(\mathrm{~m})$ & $551(w)$ & $489(w)$ & $451(w)$ & - \\
\hline$\left[\mathrm{Ni}(\mathrm{HL})(\mathrm{AcO})_{2} \mathrm{H}_{2} \mathrm{O}\right] \cdot \mathrm{H}_{2} \mathrm{O}$ & $\begin{array}{c}3351(b \\
)\end{array}$ & $1589(\mathrm{~s})$ & $1388(\mathrm{~s})$ & $1610(s)$ & $1282(\mathrm{~m})$ & $547(w)$ & $476(w)$ & $433(w)$ & - \\
\hline$\left[\mathrm{Fe}(\mathrm{HL}) \mathrm{Cl}_{3}\right] \cdot \mathrm{H}_{2} \mathrm{O}$ & $\begin{array}{c}3372(\mathrm{~b} \\
)\end{array}$ & $1517(\mathrm{~s})$ & $1405(\mathrm{~s})$ & $1608(s)$ & $1276(\mathrm{~m})$ & $563(w)$ & $493(\mathrm{~m})$ & $430(w)$ & - \\
\hline$\left[\mathrm{Co}(\mathrm{HL})(\mathrm{AcO})_{2} \mathrm{H}_{2} \mathrm{O}\right] \cdot \mathrm{H}_{2} \mathrm{O}$ & $\begin{array}{c}3309(b \\
)\end{array}$ & $1592(\mathrm{~s})$ & $1407(\mathrm{~s})$ & $1616(s)$ & $1243(\mathrm{~m})$ & $568(w)$ & $472(w)$ & $422(w)$ & - \\
\hline$\left[\mathrm{Zn}(\mathrm{HL})(\mathrm{AcO})_{2} \mathrm{H}_{2} \mathrm{O}\right] \cdot \mathrm{H}_{2} \mathrm{O}$ & $\begin{array}{c}3298(b \\
)\end{array}$ & $1588(\mathrm{~s})$ & 1393(s) & $1610(s)$ & $1273(\mathrm{~m})$ & $525(w)$ & $465(w)$ & $440(w)$ & - \\
\hline$\left[\mathrm{Hg}(\mathrm{HL})(\mathrm{AcO})_{2} \mathrm{H}_{2} \mathrm{O}\right] \cdot \mathrm{H}_{2} \mathrm{O}$ & $\begin{array}{c}3423(\mathrm{~b} \\
)\end{array}$ & $1583(\mathrm{~s})$ & $1359(\mathrm{~s})$ & $1607(\mathrm{~s})$ & $1267(\mathrm{~m})$ & $528(w)$ & $480(w)$ & $428(w)$ & - \\
\hline$\left[\mathrm{La}(\mathrm{HL})\left(\mathrm{NO}_{3}\right)_{3}\right] \cdot 2 \mathrm{H}_{2} \mathrm{O}$ & $\begin{array}{c}3392(\mathrm{~b} \\
)\end{array}$ & $1564(\mathrm{sh})$ & $1353(\mathrm{~m})$ & $1626(\mathrm{~m})$ & $1223(\mathrm{~m})$ & $546(w)$ & $484(w)$ & $432(w)$ & $\begin{array}{c}1456,1385, \\
1333,818 ; \\
\left(\mathrm{NO}_{3}^{-}\right) \\
\text {(bidentate) }\end{array}$ \\
\hline$\left[\mathrm{Sm}(\mathrm{HL})\left(\mathrm{ClO}_{4}\right)_{3}\right] \cdot 2 \mathrm{H}_{2} \mathrm{O}$ & $\begin{array}{c}3367(b \\
)\end{array}$ & $1515(\mathrm{~s})$ & 1333(m) & $1598(\mathrm{~s})$ & $1254(\mathrm{~m})$ & $590(w)$ & $528(w)$ & $470(w)$ & $\begin{array}{c}1145,1115, \\
1087,628 ; \\
\left(\mathrm{ClO}_{4}^{-}\right) \\
\text {(bidentate) }\end{array}$ \\
\hline
\end{tabular}

${ }^{\mathrm{a}} \mathrm{s}$, strong; m, medium; w, weak; b, broad. 


\section{4. ${ }^{1} \mathrm{H}$ NMR Spectra}

There is good agreement between the ${ }^{1} \mathrm{H}$ NMR spectra of the prepared compounds and their assigned structures. The chemical shifts of the different types of protons in the ${ }^{1} \mathrm{H}$ NMR spectra of the HL ligand and its diamagnetic $\mathrm{Zn}(\mathrm{II}), \mathrm{Hg}(\mathrm{II})$ and $\mathrm{La}(\mathrm{III})$ complexes are listed in Table 3 . The ${ }^{1} \mathrm{H}$ NMR spectrum of the ligand HL (Fig. 1) exhibited a broad signal at $12.69 \mathrm{ppm}$ due to hydrogen-bonded carboxylic proton [33]. This signal appeared in the ${ }^{1} \mathrm{H}$ NMR spectra of complexes at 9.62-10.20 ppm with up-field shifts, indicating the coordination of carboxylic oxygen to metal without proton displacement. The ligand also showed a singlet at $8.32 \mathrm{ppm}$ for $-\mathrm{CH}=\mathrm{N}$ which was shifted to 8.21 $8.31 \mathrm{ppm}$ in the complexes indicating the involvement of azomethine group in complexation [34]. In addition, the peaks due to hydrogen of the aromatic and furan species are slightly shifted to up ordown-field supporting the coordination of the ligand HL to metal ions.

Table3. Theimportant ${ }^{1} H$ NMR data for ligand, HL and its complexes

\begin{tabular}{|c|c|c|}
\hline Compound & Chemical shift, $\delta(\mathrm{ppm})$ & Assignment \\
\hline $\mathrm{HL}$ & 12.69 & $(\mathrm{~s}, 1 \mathrm{H}, \mathrm{COOH})$ \\
& 8.32 & $(\mathrm{~s}, 1 \mathrm{H}$, azomethine $)$ \\
& $6.47-7.8$ & $(\mathrm{~m}, 7 \mathrm{H}, 4 \mathrm{ArH}$ and 3 furan $\mathrm{H})$ \\
\hline$\left[\mathrm{Zn}(\mathrm{HL})(\mathrm{AcO})_{2} \mathrm{H}_{2} \mathrm{O}\right] \mathrm{H}_{2} \mathrm{O}$ & 10.20 & $(\mathrm{~s}, 1 \mathrm{H}, \mathrm{COOH})$ \\
& 8.21 & $(\mathrm{~s}, 1 \mathrm{H}$, azomethine $)$ \\
& $6.42-7.87$ & $(\mathrm{~m}, 7 \mathrm{H}, 4 \mathrm{ArH}$ and 3 furan $\mathrm{H})$ \\
& 3.33 & $\left(\mathrm{~s}, 4 \mathrm{H}, \mathrm{H}_{2} \mathrm{O}\right)$ \\
& 1.83 & $\left(\mathrm{~s}, 6 \mathrm{H}, \mathrm{CH}_{3} \mathrm{COO}\right)$ \\
\hline$\left[\mathrm{Hg}(\mathrm{HL})(\mathrm{AcO})_{2} \mathrm{H}_{2} \mathrm{O}_{3} \mathrm{H}_{2} \mathrm{O}\right.$ & 9.80 & $(\mathrm{~s}, 1 \mathrm{H}, \mathrm{COOH})$ \\
& 8.31 & $(\mathrm{~s}, 1 \mathrm{H}$, azomethine $)$ \\
& $6.43-7.95$ & $(\mathrm{~m}, 7 \mathrm{H}, 4 \mathrm{ArH}$ and 3 furan $\mathrm{H})$ \\
& 3.15 & $\left(\mathrm{~s}, 4 \mathrm{H}, \mathrm{H}_{2} \mathrm{O}\right)$ \\
& 1.90 & $\left(\mathrm{~s}, 6 \mathrm{H}, \mathrm{CH} \mathrm{C}_{3} \mathrm{COO}\right)$ \\
\hline$\left[\mathrm{La}(\mathrm{HL})\left(\mathrm{NO}_{3}\right)_{3}\right] 2 \mathrm{H}_{2} \mathrm{O}$ & 9.62 & $(\mathrm{~s}, 1 \mathrm{H}, \mathrm{COOH})$ \\
& $6.46-8.43$ & $(\mathrm{~m}, 8 \mathrm{H}$, azomethine $\mathrm{H}, 4 \mathrm{ArH}$ and 3 \\
& 3.34 & furan $\mathrm{H})$ \\
& & $\left(\mathrm{s}, 4 \mathrm{H}, \mathrm{H}_{2} \mathrm{O}\right)$ \\
\hline
\end{tabular}

s, singlet; $d$, doublet; $m$, multiplet; $b$, broad

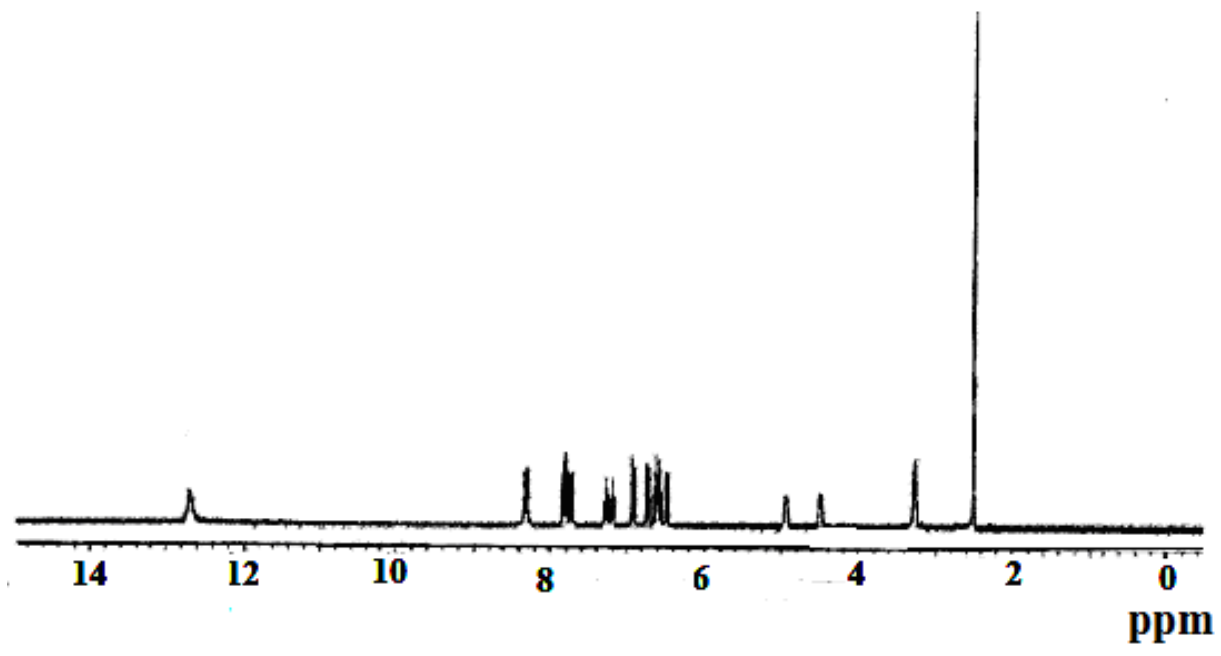

Fig1. ${ }^{1} H$ NMR spectrum of HLligand.

\subsection{Mass Spectra}

The mass spectrum of the ligand (Fig. 2) showed the molecular ion peak at 215, confirming its formula weight (F.W. 215.21). The mass spectra of the $\mathrm{Cu}$ (II), $\mathrm{Ni}$ (II), $\mathrm{Co}$ (II), $\mathrm{Zn}$ (II), $\mathrm{Hg}$ (II) and $\mathrm{Fe}$ (III) complexes provide good evidence for the molecular formulas of these complexes (S1-S6). The most prominent mass spectral peaks of the reported complexes are given in Table 4.They can be discussed as follows: 


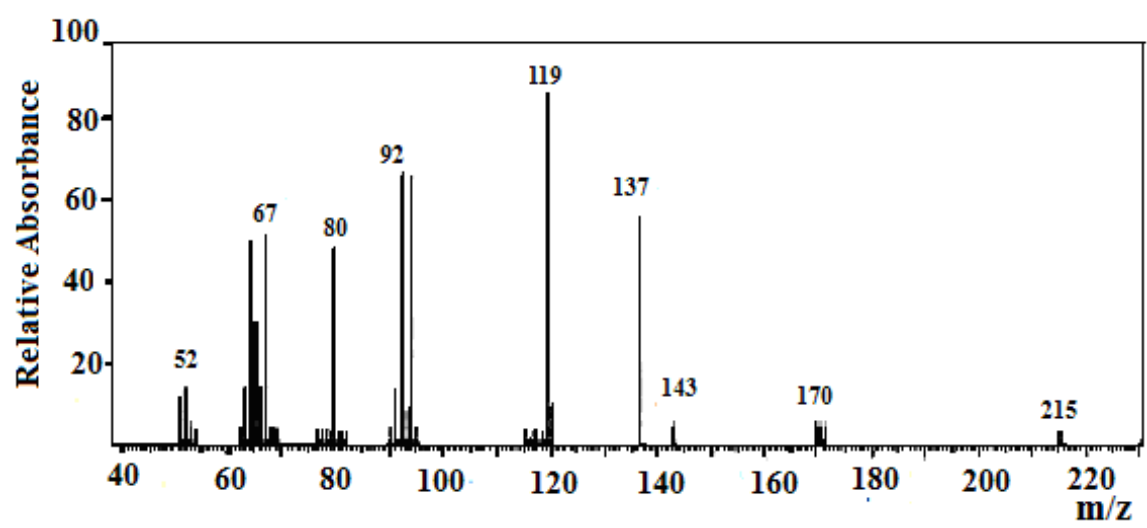

Fig2. Mass spectrum of the ligand $H L$.

Table4. The diffuse reflectance data of the Schiff base (HL) and its complexes

\begin{tabular}{|c|c|c|}
\hline Compound & $\lambda_{\max }(\mathrm{nm})$ & Band assignment \\
\hline $\mathrm{HL}$ & $\begin{array}{l}269 \\
340 \\
514\end{array}$ & $\begin{array}{c}\pi \rightarrow \pi^{*} \\
\mathrm{n} \rightarrow \pi^{*} \\
\text { charge transfer }\end{array}$ \\
\hline$\left[\mathrm{Cu}(\mathrm{HL})(\mathrm{AcO})_{2}\right] \cdot \mathrm{H}_{2} \mathrm{O}$ & $\begin{array}{c}264 \\
313 \\
347 \\
410,612 \\
\end{array}$ & $\begin{array}{c}\pi \rightarrow \pi^{*} \\
\mathrm{n} \rightarrow \pi^{*} \\
\text { charge transfer } \\
\text { d-d transitions }\end{array}$ \\
\hline $\left.\mathrm{Ni}(\mathrm{HL})(\mathrm{AcO})_{2} \mathrm{H}_{2} \mathrm{O}\right] \cdot \mathrm{H}_{2} \mathrm{O}$ & $\begin{array}{c}285 \\
315 \\
358 \\
456,660,700\end{array}$ & $\begin{array}{c}\quad \pi \rightarrow \pi^{*} \\
\mathrm{n} \rightarrow \pi^{*} \\
\text { charge transfer } \\
\text { d-d transitions }\end{array}$ \\
\hline$\left[\mathrm{Fe}(\mathrm{HL}) \mathrm{Cl}_{3}\right] \cdot \mathrm{H}_{2} \mathrm{O}$ & $\begin{array}{c}259 \\
326 \\
350 \\
470,614,655\end{array}$ & $\begin{array}{c}\pi \rightarrow \pi^{*} \\
\mathrm{n} \rightarrow \pi^{*} \\
\text { charge transfer } \\
\text { d-d transitions }\end{array}$ \\
\hline$\left[\mathrm{Co}(\mathrm{HL})(\mathrm{AcO})_{2} \mathrm{H}_{2} \mathrm{O}\right] \cdot \mathrm{H}_{2} \mathrm{O}$ & $\begin{array}{c}242 \\
268 \\
332 \\
424,571,606\end{array}$ & $\begin{array}{c}\pi \rightarrow \pi^{*} \\
\mathrm{n} \rightarrow \pi^{*} \\
\text { charge transfer } \\
\text { d-d transitions }\end{array}$ \\
\hline$\left[\mathrm{Zn}(\mathrm{HL})(\mathrm{AcO})_{2} \mathrm{H}_{2} \mathrm{O}\right] \cdot \mathrm{H}_{2} \mathrm{O}$ & $\begin{array}{c}257 \\
354 \\
411,465\end{array}$ & $\begin{array}{c}\quad \pi \rightarrow \pi^{*} \\
\mathrm{n} \rightarrow \pi^{*} \\
\text { charge transfer }\end{array}$ \\
\hline$\left[\mathrm{Hg}(\mathrm{HL})(\mathrm{AcO})_{2} \mathrm{H}_{2} \mathrm{O}\right] \cdot \mathrm{H}_{2} \mathrm{O}$ & $\begin{array}{l}260 \\
326 \\
460 \\
\end{array}$ & $\begin{array}{c}\pi \rightarrow \pi^{*} \\
\mathrm{n} \rightarrow \pi^{*} \\
\text { charge transfer }\end{array}$ \\
\hline$\left[\mathrm{La}(\mathrm{HL})\left(\mathrm{NO}_{3}\right)_{3}\right] \cdot 2 \mathrm{H}_{2} \mathrm{O}$ & $\begin{array}{c}268 \\
304,335 \\
407\end{array}$ & $\begin{array}{c}\pi \rightarrow \pi^{*} \\
\mathrm{n} \rightarrow \pi^{*} \\
\text { charge transfer }\end{array}$ \\
\hline$\left[\mathrm{Sm}(\mathrm{HL})\left(\mathrm{ClO}_{4}\right)_{3}\right] \cdot 2 \mathrm{H}_{2} \mathrm{O}$ & $\begin{array}{c}239 \\
344,376 \\
418,470 \\
539,570,606\end{array}$ & $\begin{array}{c}\pi \rightarrow \pi^{*} \\
n \rightarrow \pi^{*} \\
\text { charge transfer } \\
\text { f-f transitions }\end{array}$ \\
\hline
\end{tabular}

$\left[\mathbf{C u}(\mathbf{H L})(\mathbf{A c O})_{2}\right] . \mathbf{H}_{2} \mathbf{O}$ : The molecular ion peak is observed at $414(67.27 \%)$ (Calc.414.85). The presence of a peak at $216(69.09 \%)$ indicated the presence of ligand in the complex. The removal of the coordinated water molecule was indicated by the peak at 397 (47.27\%) (Calc.396.83). This fragment ion underwent fragmentation with a loss of 2-acetate groups to give a peak at $277(83.64 \%)$. Further fragmentation with the loss of the HL ligand gave a peak at 64 (71.82\%).

$\left[\mathbf{N i}(\mathbf{H L})(\mathbf{A c O})_{2} \mathbf{H}_{2} \mathbf{O}\right] . \mathbf{H}_{2} \mathbf{O}$ : The molecular complex ion peak is showed at $428(44.52 \%)$. The existence of the ligand was indicated by the peak at 214. The removal of hydrated and coordinated water molecules are indicated by two peaks at $410(52.05 \%)$ and 390 (48.63\%), respectively. This 
fragment ion underwent fragmentation with the loss of the 2-acetate groups giving a peak at 274 $(67.12 \%)$ (Calc. 273.93). Further fragmentation gave a peak at 61 due to loss of the ligand (HL).

$\left[\mathbf{F e}(\mathbf{H L})(\mathbf{C l})_{3}\right] . \mathbf{H}_{2} \mathbf{O}$ : The molecular ion peak of the complex isobserved at 395 (91.30\%) (Calc. 395.43). The removal of ligand (HL) was indicated by the ion peak at 179 (63.04 \%) (Calc. 180.36). The removal of one chlorine atom and a hydrated water molecule are indicated by the peaks at 147 and 128 , respectively.

$\left[\mathbf{C o}(\mathbf{H L})(\mathbf{A c O})_{2} \mathbf{H}_{2} \mathbf{O}\right] \cdot \mathbf{H}_{2} \mathrm{O}$ : The molecular ion peak of the complex isobserved at $428(91.49 \%)$. The removal of two acetate groups gave a peak at 310 (75.53 \%) (Calc. 310.17). This fragment ion underwent fragmentation with the loss of a hydrated water molecule giving a peak at $292(60.64 \%)$. Further fragmentation ion peak was observed at 59 (78.72\%) (Calc. 58.93) referred to the loss of both a ligand molecule and $\mathrm{H}_{2} \mathrm{O}$.

$\left[\mathbf{Z n}(\mathbf{H L})(\mathbf{A c O})_{2} \mathbf{H}_{2} \mathbf{O}\right] . \mathbf{H}_{2} \mathbf{O}$ : The molecular ion peak is observed at $434(100.00 \%)$ (Calc. 434. 70). The existence of ligand (HL) is indicated by the peak at 213 (92.11\%) (Calc. 215.21). The removal of the coordinated water molecule is indicated by the peak at 415 (64.04\%) (Calc. 416.68). This fragment ion underwent fragmentation with loss of water molecule and 2-acetate groups gave two peaks at 398 and 280 (52.63 and $54.39 \%$ ) (Calc. 398.66 and 280.58), respectively. Further fragmentation with the loss of the HL ligand gave a peak at 63 (52.63\%) (Calc. $65.37 \mathrm{amu}$ ).

$\left[\mathbf{H g}(\mathbf{H L})(\mathbf{A c O})_{2} \mathbf{H}_{2} \mathbf{O}\right] . \mathbf{H}_{2} \mathrm{O}$ : The molecular ion peak is shown at $569(80.91 \%)$ (Calc. 569.92). The existence of ligand is indicated by the peak at $214(60.01 \%)$. The removal of hydrated and coordinated water molecules are indicated by two peaks at $550(51.82 \%)$ and $534(73.64 \%)$, respectively. This fragment ion underwent fragmentation with the loss of the 2-acetate groups gave a peak at $476(73.64 \%)$ and $414(57.29 \%)$ (Calc. 474.85 and 415.80). Further fragmentation with loss of the ligand (HL) gave a peak at 202 (57.27 \%) (Calc. 200.59).

\subsection{Magnetic Moments and Electronic Spectra}

In this part, we would like to elucidate the important role played by magnetic and electronic spectra in determining the geometrical structures of the investigated metal complexes. The diffuse reflectance spectra of the Schiff base ligand exhibited three bands at 269, 340 and $514 \mathrm{~nm}$ which may be assigned to $\pi-\pi^{*}, \mathrm{n}-\pi^{*}$ and charge transfer transition. The data are summarized in Table 4.

A square-pyramidal structure is proposed for $\mathrm{Cu}(\mathrm{II})$ complex based on the presence of two bands at 612 and $410 \mathrm{~nm}[35]$. These may be assigned to ${ }^{2} \mathrm{~B}_{1 \mathrm{~g}} \rightarrow{ }^{2} \mathrm{~A}_{1 \mathrm{~g}}$ and ${ }^{2} \mathrm{~B}_{1 \mathrm{~g}} \rightarrow{ }^{2} \mathrm{E}_{\mathrm{g}}$ transitions, respectively. The value of the magnetic moment (1.79 B.M.) is in accordance with previous results. The Ni(II) complex has magnetic moment value of 3.81 B.M., which is in the normal range of octahedral Ni(II) complex $\left(\mu_{\mathrm{eff}}=2.82 \mathrm{~B} . \mathrm{M}\right.$.). The electronic spectrum of $\mathrm{Ni}$ (II) complex displayed three bands in the solid reflectance spectrum at $v_{1}\left(700 \mathrm{~nm}:{ }^{3} \mathrm{~A}_{2 \mathrm{~g}} \rightarrow{ }^{3} \mathrm{~T}_{2 \mathrm{~g}}\right) ; v_{2}\left(660 \mathrm{~nm}:{ }^{3} \mathrm{~A}_{2 \mathrm{~g}} \rightarrow{ }^{3} \mathrm{~T}_{1 \mathrm{~g}}(\mathrm{~F})\right)$ and $v_{3}(456 \mathrm{~nm}$ : $\left.{ }^{3} \mathrm{~A}_{2 \mathrm{~g}} \rightarrow{ }^{3} \mathrm{~T}_{1 \mathrm{~g}}(\mathrm{P})\right)$ [36]. The spectrum showed also a band at $358 \mathrm{~nm}$ which may attribute to ligand to metal charge transfer. The diffuse reflectance spectrum of Fe(III) complex exhibits a band at $470 \mathrm{~nm}$ which may be assigned to ${ }^{6} \mathrm{~A}_{1 \mathrm{~g}} \rightarrow \mathrm{T}_{2 \mathrm{~g}}(\mathrm{G})$ transition in octahedral geometry of the complex [37]. The ${ }^{6} \mathrm{~A}_{1 \mathrm{~g}} \rightarrow{ }^{5} \mathrm{~T}_{1 \mathrm{~g}}$ transition appears to be split into two bands at 614 and $655 \mathrm{~nm}$. The observed magnetic moment of Fe (III) complex is 5.73 B.M. indicating octahedral geometry [38]. The spectrum shows also a band at $350 \mathrm{~nm}$ which may attributed to ligand to metal charge transfer. The diffuse reflectance spectrum of the Co (II) complex showed three bands at 424, 571 and $606 \mathrm{~nm}$. The bands observed are assigned to the transition ${ }^{4} \mathrm{~T}_{1 \mathrm{~g}}(\mathrm{~F}) \rightarrow{ }^{4} \mathrm{~T}_{1 \mathrm{~g}}(\mathrm{P})\left(v_{3}\right),{ }^{4} \mathrm{~T}_{1 \mathrm{~g}}(\mathrm{~F}) \rightarrow{ }^{4} \mathrm{~A}_{2 \mathrm{~g}}(\mathrm{~F})\left(v_{2}\right)$ and ${ }^{4} \mathrm{~T}_{1 \mathrm{~g}}(\mathrm{~F}) \rightarrow{ }^{2} \mathrm{~T}_{2 \mathrm{~g}}(\mathrm{~F})\left(v_{1}\right)$, respectively, suggesting octahedral structure around $\mathrm{Co}(\mathrm{II})$ ion [38]. The magnetic moment value of Co (II) complex has been found to be $4.52 \mathrm{BM}$ corresponding to three unpaired electrons within the range of high spin octahedral complex of $\mathrm{Co}(\mathrm{II})$ ion [34]. The diffuse reflectance spectra of $\mathrm{Zn}(\mathrm{II})$, $\mathrm{Hg}$ (II), La(III) and Sm(III) complexes, showed $\pi-\pi^{*}$ and $\mathrm{n}-\pi^{*}$ bands in addition to another bands displayed in the range 407 to $470 \mathrm{~nm}$ attributed to ligand to metal charge transfer. The shift of these bands in the spectra of complexes indicated the formation of their metal complexes. As expected for the diamagnetic $\mathrm{Zn}(\mathrm{II})$ and $\mathrm{Hg}(\mathrm{II})\left(\mathrm{d}^{10}\right)$ and $\mathrm{La}(\mathrm{III})\left(\mathrm{d}^{0}\right)$ configurations, ligand field band due to $d-d$ electronic transitions is not expected [39] and the trends observed for the ligand were maintained after coordination. 
Spectroscopic, Thermal, Fluorescence Studies and Antibacterial Activity of Some Transition Metals with Schiff Base 2-[(2-Furylmethylene) Amino] Benzoic Acid

\subsection{Luminescence spectral study}

The fluorescence characteristic of the ligand HL and its complexes were listed in Table 5. The free ligand exhibits a broad emission band at $405 \mathrm{~nm}$ in DMSO solution when excited at $348 \mathrm{~nm}$ due to intraligand $\pi \rightarrow \pi^{*}$ transitions. All complexes (Fig. 3) exhibited a blue shift. The spectra of metal complexes exhibited a strong fluorescence emission band in the range 397-462 nm. Co(II) complex upon excitation at $320 \mathrm{~nm}$ gives a broad emission band at $462 \mathrm{~nm}$ with fluorescence intensity 3887 and a shoulder at $399 \mathrm{~nm}$. The intensity of emission of this band is decreased with respect to ligand. Significant differences in the positions of emission maximum of Schiff base and its complexes establish the coordination of the metal ion to the ligand. The $\mathrm{Zn}$ (II) and Fe (III) complexes gave a highly fluorescence properties than other complexes and free ligand. Thus, this study introduce new compounds could be anticipated as potential fluorescence materials in visible light [40].

Table5. Fluorescence data of HL ligand and its complexes

\begin{tabular}{|c|c|c|}
\hline Compound & $\lambda_{\text {ex }}(\mathrm{nm})$ & $\lambda_{\text {em }}(\mathrm{nm})$ \\
\hline $\mathrm{HL}$ & 348 & 405 \\
\hline$\left[\mathrm{Cu}(\mathrm{HL})(\mathrm{AcO})_{2}\right] \cdot \mathrm{H}_{2} \mathrm{O}$ & 348 & 405 \\
\hline$\left[\mathrm{Ni}(\mathrm{HL})(\mathrm{AcO})_{2} \mathrm{H}_{2} \mathrm{O}\right] \cdot \mathrm{H}_{2} \mathrm{O}$ & 306 & 399 \\
\hline$\left[\mathrm{Fe}(\mathrm{HL}) \mathrm{Cl}_{3}\right] \cdot \mathrm{H}_{2} \mathrm{O}$ & 334 & 397 \\
\hline$\left[\mathrm{Co}(\mathrm{HL})(\mathrm{AcO})_{2} \mathrm{H}_{2} \mathrm{O}\right] \cdot \mathrm{H}_{2} \mathrm{O}$ & 320 & 399,462 \\
\hline$\left[\mathrm{Zn}(\mathrm{L})(\mathrm{AcO})_{2} \mathrm{H}_{2} \mathrm{O}\right] \cdot \mathrm{H}_{2} \mathrm{O}$ & 338 & 398 \\
\hline$\left[\mathrm{Hg}(\mathrm{L})(\mathrm{AcO})_{2} \mathrm{H}_{2} \mathrm{O}\right] \cdot \mathrm{H}_{2} \mathrm{O}$ & 338 & 398 \\
\hline$\left[\mathrm{La}(\mathrm{HL})\left(\mathrm{NO}_{3}\right)_{3}\right] \cdot 2 \mathrm{H}_{2} \mathrm{O}$ & 328 & 397 \\
\hline$\left[\mathrm{Sm}(\mathrm{HL})\left(\mathrm{ClO}_{4}\right)_{3}\right] \cdot 2 \mathrm{H}_{2} \mathrm{O}$ & 356 & 402 \\
\hline
\end{tabular}

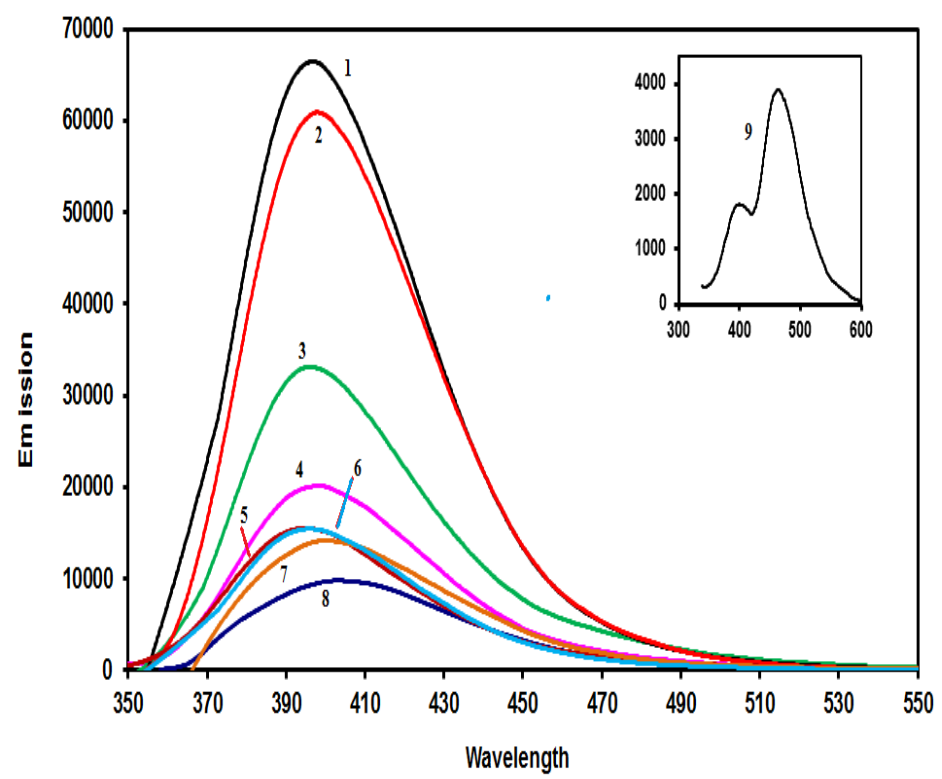

Fig3. Emission spectra of: (1) $\left[\mathrm{Zn}(\mathrm{HL})(\mathrm{AcO})_{2} \mathrm{H}_{2} \mathrm{O}\right] \mathrm{H}_{2} \mathrm{O}$; (2) $\left[\mathrm{Fe}(\mathrm{HL}) \mathrm{Cl}_{3}\right] \mathrm{H}_{2} \mathrm{O}$ (3) [Ni(HL) $\left.(\mathrm{AcO})_{2} \mathrm{H}_{2} \mathrm{O}\right] \mathrm{H}_{2} \mathrm{O}$; (4) $\left[\mathrm{Cu}(\mathrm{HL})(\mathrm{AcO})_{2} \mathrm{H}_{2} \mathrm{O}\right]$; (5) [ $\left.\mathrm{La}(\mathrm{HL})\left(\mathrm{NO}_{3}\right)_{3}\right] 2 \mathrm{H}_{2} \mathrm{O}$; (6) $\left[\mathrm{Hg}(\mathrm{HL})(\mathrm{AcO})_{2} \mathrm{H}_{2} \mathrm{O}\right] \mathrm{H}_{2} \mathrm{O}$; (7) [ $\left.\mathrm{Sm}(\mathrm{HL})\left(\mathrm{ClO}_{4}\right)_{3}\right] 2 \mathrm{H}_{2} \mathrm{O}$; (8) Schiff base ligand $\mathrm{HL}$ and (9) $\left[\mathrm{Co}(\mathrm{HL})(\mathrm{AcO})_{2} \mathrm{H}_{2} \mathrm{O}\right] \mathrm{H}_{2} \mathrm{O}$.

\subsection{Thermal Analysis}

The presence of water molecules and the thermal decomposition studies of the complexes could be achieved by thermal analysis. The TGA results of the Schiff base and its complexes are listed in Table 6.

Table6. Thermogravimetric data of ligand and its complexes

\begin{tabular}{|c|c|c|c|c|}
\hline Compound & TG range $\left({ }^{\circ} \mathrm{C}\right)$ & Mass loss & Assignment & $\begin{array}{c}\text { Metallic residue }(\%) \\
\text { Found (Calc.) }\end{array}$ \\
\cline { 3 - 3 } & & \% Found (Calc.) & & - \\
\hline $\mathrm{HL}$ & $26-387$ & $44.33(44.19)$ & Loss of $\mathrm{C}_{5} \mathrm{H}_{5} \mathrm{NO}_{1}$ & \\
& $387-752$ & $55.67(55.81)$ & Loss of $\mathrm{C}_{7} \mathrm{H}_{4} \mathrm{O}_{2}$ & \\
\hline$\left[\mathrm{Cu}(\mathrm{HL})(\mathrm{AcO})_{2}\right] \cdot \mathrm{H}_{2} \mathrm{O}$ & $50-186$ & $4.14(4.34)$ & Loss of $\mathrm{H}_{2} \mathrm{O}$ & $\mathrm{CuO} 19.19(19.18)$ \\
& $186-955$ & $76.67(76.48)$ & Loss of 2(AcO) and $\mathrm{HL}$ & \\
\hline
\end{tabular}


Spectroscopic, Thermal, Fluorescence Studies and Antibacterial Activity of Some Transition Metals with Schiff Base 2-[(2-Furylmethylene) Amino] Benzoic Acid

\begin{tabular}{|c|c|c|c|c|}
\hline$\left[\mathrm{Ni}(\mathrm{HL})(\mathrm{AcO})_{2} \mathrm{H}_{2} \mathrm{O}\right] \cdot \mathrm{H}_{2} \mathrm{O}$ & $\begin{array}{c}29-76 \\
76-629\end{array}$ & $\begin{array}{c}4.22(4.21) \\
77.89(78.34)\end{array}$ & $\begin{array}{c}\text { Loss of } \mathrm{H}_{2} \mathrm{O} \\
\text { Loss of } \mathrm{H}_{2} \mathrm{O}, 2(\mathrm{AcO}) \\
\text { and } \mathrm{HL}\end{array}$ & $\mathrm{NiO} 17.89(17.45)$ \\
\hline$\left[\mathrm{Fe}(\mathrm{HL}) \mathrm{Cl}_{3}\right] \cdot \mathrm{H}_{2} \mathrm{O}$ & $\begin{array}{c}39-140 \\
140-1000\end{array}$ & $\begin{array}{c}4.46(4.55) \\
75.35(75.26)\end{array}$ & $\begin{array}{c}\text { Loss of } \mathrm{H}_{2} \mathrm{O} \\
\text { Loss of } 3 \mathrm{Cl} \text { and } \mathrm{HL}\end{array}$ & $\begin{array}{c}1 / 2 \mathrm{Fe}_{2} \mathrm{O}_{3} 20.19 \\
(20.19)\end{array}$ \\
\hline$\left[\mathrm{Co}(\mathrm{HL})(\mathrm{AcO})_{2} \mathrm{H}_{2} \mathrm{O}\right] \cdot \mathrm{H}_{2} \mathrm{O}$ & $\begin{array}{c}40-100 \\
100-610\end{array}$ & $\begin{array}{c}4.71(4.21) \\
82.11(82.03)\end{array}$ & $\begin{array}{c}\text { Loss of } \mathrm{H}_{2} \mathrm{O} \\
\text { Loss of } \mathrm{H}_{2} \mathrm{O}, 2(\mathrm{AcO}) \\
\text { and } \mathrm{HL}\end{array}$ & $\mathrm{CoO} 13.18(13.76)$ \\
\hline$\left[\mathrm{Zn}(\mathrm{L})(\mathrm{AcO})_{2} \mathrm{H}_{2} \mathrm{O}\right] \cdot \mathrm{H}_{2} \mathrm{O}$ & $\begin{array}{c}34-133 \\
133-573\end{array}$ & $\begin{array}{c}4.15(4.14) \\
77.67(77.14)\end{array}$ & $\begin{array}{c}\text { Loss of } \mathrm{H}_{2} \mathrm{O} \\
\text { Loss of } \mathrm{H}_{2} \mathrm{O}, 2(\mathrm{AcO}) \\
\text { and } \mathrm{HL}\end{array}$ & $\mathrm{ZnO} 18.18$ (18.72) \\
\hline$\left[\mathrm{Hg}(\mathrm{L})(\mathrm{AcO})_{2} \mathrm{H}_{2} \mathrm{O}\right] \cdot \mathrm{H}_{2} \mathrm{O}$ & $\begin{array}{c}29-98 \\
98-265 \\
265-849\end{array}$ & $\begin{array}{c}3.15(3.16) \\
61.49(61.64) \\
35.36(35.20)\end{array}$ & $\begin{array}{c}\text { Loss of } \mathrm{H}_{2} \mathrm{O} \\
\text { Loss of } \mathrm{H}_{2} \mathrm{O}, 2(\mathrm{AcO}) \\
\text { and } \mathrm{HL} \text { Loss of } \mathrm{Hg}\end{array}$ & No residue \\
\hline$\left[\mathrm{La}(\mathrm{HL})\left(\mathrm{NO}_{3}\right)_{3}\right] \cdot 2 \mathrm{H}_{2} \mathrm{O}$ & $\begin{array}{c}38-125 \\
125-414 \\
414-999\end{array}$ & $\begin{array}{c}6.32(6.25) \\
32.31(32.29) \\
33.00(33.19)\end{array}$ & $\begin{array}{c}\text { Loss of } 2\left(\mathrm{H}_{2} \mathrm{O}\right) \\
\text { Loss of } 3\left(\mathrm{NO}_{3}\right) \\
\text { Loss of } \mathrm{HL}\end{array}$ & $\begin{array}{c}1 / 2 \mathrm{La}_{2} \mathrm{O}_{3} 28.37 \\
(28.27)\end{array}$ \\
\hline$\left[\mathrm{Sm}(\mathrm{HL})\left(\mathrm{ClO}_{4}\right)_{3}\right] \cdot 2 \mathrm{H}_{2} \mathrm{O}$ & $\begin{array}{c}30-208 \\
208-492 \\
492-730\end{array}$ & $\begin{array}{c}5.18(5.15) \\
42.35(42.62) \\
27.58(27.32)\end{array}$ & $\begin{array}{c}\text { Loss of } 2\left(\mathrm{H}_{2} \mathrm{O}\right) \\
\text { Loss of } 3\left(\mathrm{ClO}_{4}\right) \\
\text { Loss of } \mathrm{HL}\end{array}$ & $\begin{array}{c}1 / 2 \mathrm{Sm}_{2} \mathrm{O}_{3} \\
24.89(24.91)\end{array}$ \\
\hline
\end{tabular}

The TGA curve of Schiff base HL exhibits a first mass loss of $44.33 \%$ (Calc. $44.19 \%$ ) at $26-387^{\circ} \mathrm{C}$ attributed to the liberation of $\mathrm{C}_{5} \mathrm{H}_{5} \mathrm{NO}$ moiety. In the $2^{\text {nd }}$ stage within the temperature range $387-752$ ${ }^{\circ} \mathrm{C}$, the ligandloses the remaining part with mass loss of $55.67 \%$ (Calc. 55.81\%). This decomposition step assigned to the elimination of $\mathrm{C}_{7} \mathrm{H}_{4} \mathrm{O}_{2}$ organic moiety.

The TGA curve of the $\mathrm{Cu}$ (II) complex showed two decomposition steps within the temperature range $50-955{ }^{\circ} \mathrm{C}$. The first step corresponds to the loss of a hydrated water molecule, with a mass loss of $4.14 \%$ (Calc. $4.34 \%$ ). The second step of decomposition within the temperature range $186-955{ }^{\circ} \mathrm{C}$ with a net weight loss of $76.67 \%$ (Calc. $76.48 \%$ ). This decomposition step has been assigned to the elimination of $2\left(\mathrm{AcO}^{-}\right)$and ligand species to give finally $\mathrm{CuO}$ as a residue.

The TGA curve of the Ni(II) complex (Fig. 4) showed two stages of decomposition within the temperature range $29-629^{\circ} \mathrm{C}$. The first stage at $29-76^{\circ} \mathrm{C}$ corresponded to the loss of water molecule of hydration. The second stage involves the loss of a coordinated water molecule, two acetate groups and a ligand molecule to give finally NiOas a residue.

The TGA curve of $\mathrm{Fe}$ (III) complex(Fig. 4)exhibited two decomposition steps within the temperature range $39-1000{ }^{\circ} \mathrm{C}$. The first decomposition step is within the temperature range $39-140{ }^{\circ} \mathrm{C}$ corresponding to the loss of a hydrated water molecule. The second step was corresponded to the removal of $3 \mathrm{Cl}^{-}+\mathrm{HL}$ with a net weight loss of $75.35 \%$ (Calc. $75.26 \%$ ) leaving $1 / 2 \mathrm{Fe}_{2} \mathrm{O}_{3}$ as a residue. The TG curve of Co(II) complex displayed a similar decomposition pattern with two decomposition steps. The first decomposition step is consistent with the loss of a hydrated water molecule, whereas the second step involved removal of a coordinated water molecule, two acetate groups and organic ligand moiety, leaving CoOas a residue.

The TGA curve of the $\mathrm{Zn}$ (II) complex showed two decomposition steps within the temperature range $34-573{ }^{\circ} \mathrm{C}$. The first step of decomposition corresponds to the loss of a hydrated water molecule, with a mass loss of $4.15 \%$ (Calc. $4.14 \%$ ). The second decomposition step has been assigned to the elimination of a coordinated $\mathrm{H}_{2} \mathrm{O}, 2\left(\mathrm{AcO}^{-}\right)$and a ligand moiety to give finally $\mathrm{ZnOas}$ a residue.

The TGA curve of the $\mathrm{Hg}$ (II) complex (Fig. 4) showed three decomposition stages within the temperature range $29-849{ }^{\circ} \mathrm{C}$. The first stage at $29-98^{\circ} \mathrm{C}$ corresponds to the loss of a hydrated water molecule, with a mass loss of $3.15 \%$ (Calc. $3.16 \%$ ). The second stage involves a loss of coordinated water molecule, two acetate moieties and ligand molecule. The third stepwascorresponded to the loss of Hgwithout any residue due to the evaporation of $\mathrm{Hg}$.

The TGA curve of $\mathrm{La}(\mathrm{III})$ complex exhibited three decomposition steps within the temperature range 38-999 ${ }^{\circ} \mathrm{C}$. The first decomposition step was corresponded to the loss of two hydrated water molecules, with a mass loss of $6.32 \%$ (Calc. $6.25 \%$ ). The second and third steps correspond to the removal of $3\left(\mathrm{NO}_{3}{ }^{-}\right)$and a ligand molecule, respectively leaving $1 / 2 \mathrm{La}_{2} \mathrm{O}_{3}$ as a residue. 
The TG curve of $\left[\mathrm{Sm}(\mathrm{HL})\left(\mathrm{ClO}_{4}\right)_{3}\right] \cdot 2 \mathrm{H}_{2} \mathrm{O}$ complex (Fig. 4) displayed a similar decomposition pattern with three decomposition steps. The first decomposition step is consistent with loss of two hydrated water molecules, whereas the second and third steps involved removal of $3\left(\mathrm{ClO}_{4}{ }^{-}\right)$species and an organic ligand moiety, respectively leaving $1 / 2 \mathrm{Sm}_{2} \mathrm{O}_{3}$ as a final residue.
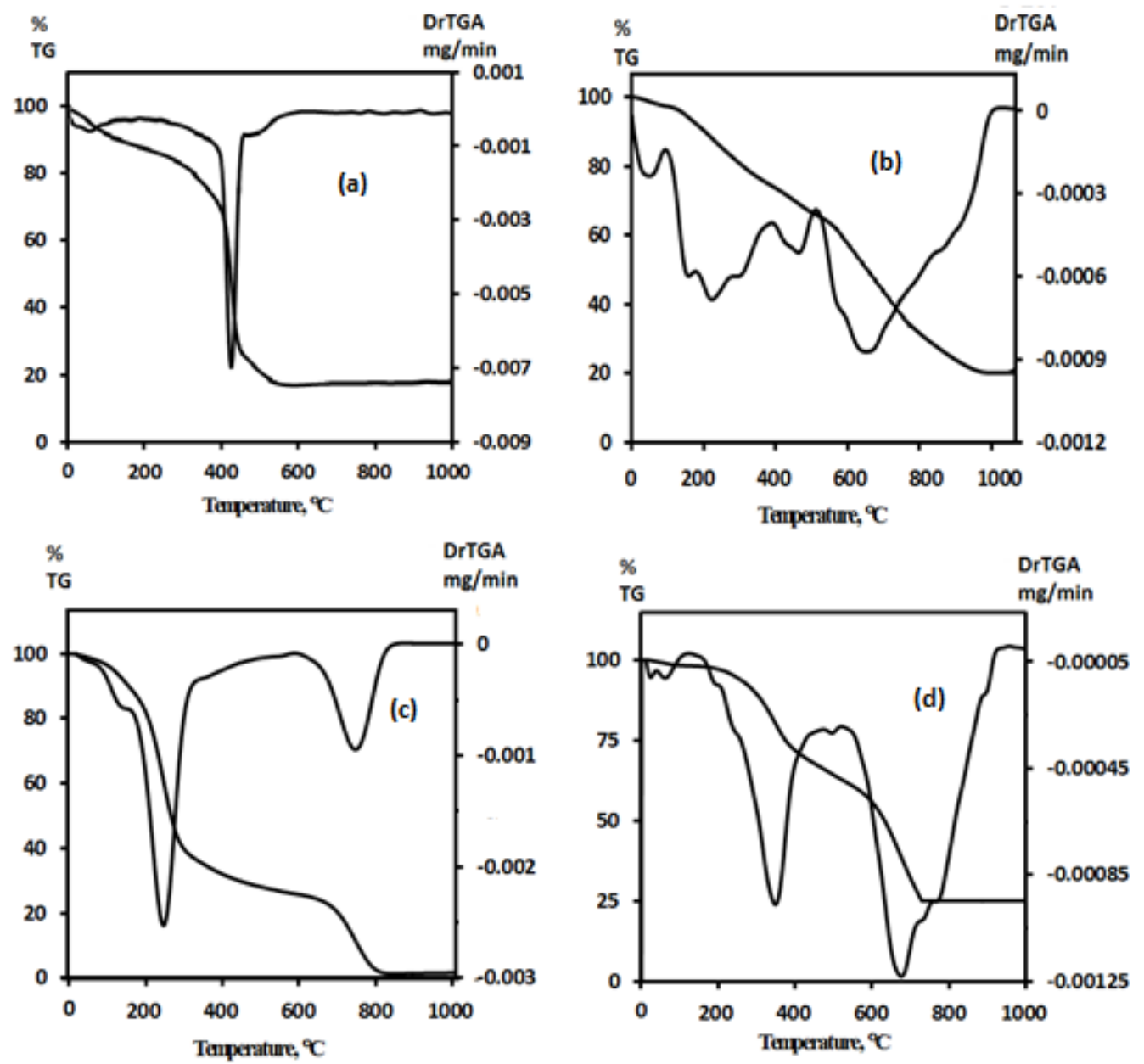

Fig4. TG and DTG curves of : (a) $\left[\mathrm{Ni}(\mathrm{HL})(\mathrm{AcO})_{2} \mathrm{H}_{2} \mathrm{O}\right] \mathrm{H}_{2} \mathrm{O}$; (b) $\left[\mathrm{Fe}(\mathrm{HL}) \mathrm{Cl}_{3}\right] \mathrm{H}_{2} \mathrm{O}$; (C) $\left[\mathrm{Hg}(\mathrm{HL})(\mathrm{AcO})_{2} \mathrm{H}_{2} \mathrm{O}\right] \mathrm{H}_{2} \mathrm{O}$ and $(d)\left[\mathrm{Sm}(\mathrm{HL})\left(\mathrm{ClO}_{4}\right)_{3}\right] 2 \mathrm{H}_{2} \mathrm{O}$

\subsection{Corrosion Inhibition}

Weight loss measurements of the SS in $1 \mathrm{M} \mathrm{H}_{2} \mathrm{SO}_{4}$ in the absence and the presence of different concentrations of the studied inhibitors were carried out at $25^{\circ} \mathrm{C}$ and the results are reported in Table 7. As shown from the results, the corrosion rate (R) of the SS decreased in the presence of the additives and the inhibition efficiency increased with the increase in the inhibitor concentration (Fig. 5) [23].The maximum efficiency of the ligand on stainless steel 410 , is $78 \%$ at $1 \times 10^{-3} \mathrm{M} \mathrm{HL}$ concentration,. The maximum efficiencies for the $\mathrm{Cu}(\mathrm{II}), \mathrm{Ni}(\mathrm{II})$ and $\mathrm{Co}(\mathrm{II})$ complexes are $74 \%$ for 1 $\times 10^{-4} \mathrm{M}\left[\mathrm{Cu}(\mathrm{HL})(\mathrm{AcO})_{2}\right] \cdot \mathrm{H}_{2} \mathrm{O}, 92 \%$ for $1 \times 10^{-3} \mathrm{M}\left[\mathrm{Ni}(\mathrm{HL})(\mathrm{AcO})_{2} \mathrm{H}_{2} \mathrm{O}\right] \cdot \mathrm{H}_{2} \mathrm{O}$ and $62 \%$ for $1 \times 10^{-4}$ $\mathrm{M}\left[\mathrm{Co}(\mathrm{HL})(\mathrm{AcO})_{2} \mathrm{H}_{2} \mathrm{O}\right] \cdot \mathrm{H}_{2} \mathrm{O}$. Also, the maximum efficiencies for $\mathrm{Zn}$ (II), $\mathrm{Hg}$ (II) and $\mathrm{La}(\mathrm{III})$ complexes are $88 \%$ for the concentration of $1 \times 10^{-3} \mathrm{M}\left[\mathrm{Zn}(\mathrm{HL})(\mathrm{AcO})_{2} \mathrm{H}_{2} \mathrm{O}\right] \cdot \mathrm{H}_{2} \mathrm{O}, 80 \%$ for the concentration of $1 \times 10^{-5} \mathrm{M}\left[\mathrm{Hg}(\mathrm{HL})(\mathrm{AcO})_{2} \mathrm{H}_{2} \mathrm{O}\right] \cdot \mathrm{H}_{2} \mathrm{O}$ and $89 \%$ for the concentration of $1 \times 10^{-3} \mathrm{M}$ $\left[\mathrm{La}(\mathrm{HL})\left(\mathrm{NO}_{3}\right)_{3}\right] \cdot 2 \mathrm{H}_{2} \mathrm{O}$. A concentration of $10^{-4} \mathrm{M}$ of $\mathrm{La}$ (III) and $\mathrm{Zn}$ (II) complexes gives the highest value for inhibition efficiency. This indicates a good corrosion inhibition for stainless steel 410 . The inhibition efficiency of these compounds can be illustrated on the basis of their larger molecular size and electron donating nature leading to a larger surface coverage of the metal and high bond strength between the molecule and the metal surface. This was indicated by the fact that: with increasing the inhibitor concentration, both $(\theta)$ and $(\eta)$ were increased while $(R)$ was reduced (Table 7). So, the dissolution of stainless steel in the presence of the investigated inhibitors can be interpreted on the basis of interface inhibition mode, the inhibitors act effectively at the metal solution interface [41]. 
Spectroscopic, Thermal, Fluorescence Studies and Antibacterial Activity of Some Transition Metals with Schiff Base 2-[(2-Furylmethylene) Amino] Benzoic Acid

Table7. Corrosion parameters of stainless steel 410 in $1 \mathrm{M} \mathrm{H}_{2} \mathrm{SO}_{4}$ at different concentrations of inhibitors.

\begin{tabular}{|c|c|c|c|c|}
\hline Inhibitor & $\mathrm{C}_{\mathrm{inh}}(\mathrm{M})$ & $\mathrm{R}\left(\mathrm{mg} \mathrm{cm}^{-2} \mathrm{~h}^{-1}\right)$ & $\theta$ & $\eta(\%)$ \\
\hline Blank & - & 0.88 & - & - \\
\hline $\mathrm{HL}$ & $1 \times 10^{-4}$ & 0.58 & 0.40 & 60 \\
& $5 \times 10^{-4}$ & 0.35 & 0.60 & 78 \\
\hline$\left[\mathrm{Cu}(\mathrm{HL})(\mathrm{AcO})_{2}\right] \cdot \mathrm{H}_{2} \mathrm{O}$ & $1 \times 10^{-3}$ & 0.20 & 0.78 & 50 \\
& $1 \times 10^{-5}$ & 0.48 & 0.50 & 71 \\
& $5 \times 10^{-5}$ & 0.26 & 0.71 & 74 \\
\hline$\left[\mathrm{Ni}(\mathrm{HL})(\mathrm{AcO})_{2} \mathrm{H}_{2} \mathrm{O}\right] \cdot \mathrm{H}_{2} \mathrm{O}$ & $1 \times 10^{-4}$ & 0.23 & 0.74 & 84 \\
& $1 \times 10^{-4}$ & 0.20 & 0.74 & 92 \\
\hline$\left[\mathrm{Co}(\mathrm{HL})(\mathrm{AcO})_{2} \mathrm{H}_{2} \mathrm{O}\right] \cdot \mathrm{H}_{2} \mathrm{O}$ & $5 \times 10^{-4}$ & 0.11 & 0.88 & 30 \\
& $1 \times 10^{-3}$ & 0.07 & 0.92 & 62 \\
\hline$\left[\mathrm{Zn}(\mathrm{HL})(\mathrm{AcO})_{2} \mathrm{H}_{2} \mathrm{O}\right] \cdot \mathrm{H}_{2} \mathrm{O}$ & $1 \times 10^{-6}$ & 0.30 & 0.30 & 62 \\
& $1 \times 10^{-4}$ & 0.47 & 0.46 & 81 \\
& $1 \times 10^{-5}$ & 0.34 & 0.62 & 88 \\
\hline$\left[\mathrm{Hg}(\mathrm{HL})(\mathrm{AcO})_{2} \mathrm{H}_{2} \mathrm{O}\right] \cdot \mathrm{H}_{2} \mathrm{O}$ & $1 \times 10^{-4}$ & 0.33 & 0.62 & 34 \\
& $1 \times 10^{-3}$ & 0.17 & 0.81 & 55 \\
& $1 \times 10^{-6}$ & 0.10 & 0.88 & 80 \\
\hline$\left[\mathrm{La}(\mathrm{HL})(\mathrm{NO})_{3}\right] \cdot 2 \mathrm{H}_{2} \mathrm{O}$ & $5 \times 10^{-6}$ & 0.58 & 0.34 & 55 \\
& $1 \times 10^{-5}$ & 0.40 & 0.55 & 81 \\
\hline
\end{tabular}
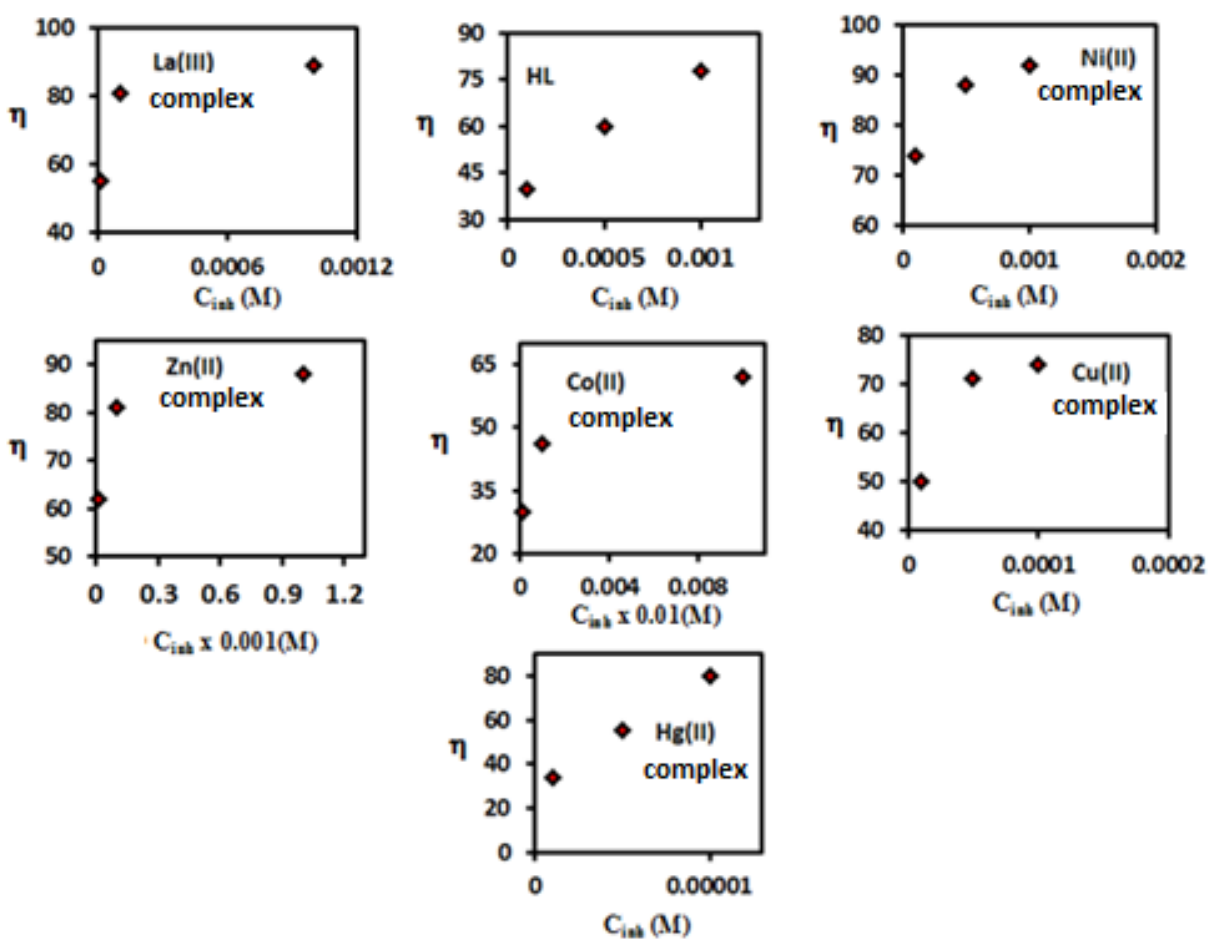

Fig5. Plot of inhibition efficiency against inhibitor concentrations.

\subsection{Antibacterial Activity}

The Schiff base HL ligand and its metal complexes are evaluated for antibacterial activity against two Gram-positive bacteria (B. Subtilis and S. aureus) and two Gram-negative bacteria (E.coli and P. aeruginosa). The antibacterial activities of the prepared compounds are listed in Table 8. All the investigated compounds showed a remarkable biological activity against bacteria (Fig. 6).The obtained results reflect that; (1) The metal complexes of $\mathrm{Cu}(\mathrm{II}), \mathrm{Ni}(\mathrm{II})$ and $\mathrm{La}(\mathrm{III})$ possess moderate antibacterial activity; (2) $\mathrm{Fe}$ (III) and $\mathrm{Sm}$ (III) complexes showed low activity against all studied 
bacteria; (3) Co (II) and Zn (II) complex showed higher antibacterial activity more than that of ligand; (4) $\mathrm{Hg}$ (II) complex against $S$. aureus is more potent than the standard antibiotics and showed the highest activity against $B$. Subtilis and E. Coli. (5) $\mathrm{Hg}(\mathrm{II})$ complex against $P$. aeruginosa is the same activity as the standard antibiotics. On chelation, the delocalization of $\pi$-electrons over the whole chelate ring will be increased which enhances the penetration of the complexes into lipid membranes and blocking the metal binding sites in the enzymes of microorganisms. Also, the tested complexes may disturb the respiration process of the cell and consequently block the synthesis of proteins leading to no further growth of the organisms [42]. The variation in the activity values of different compounds against different organisms depends on either the impermeability of the cells of the microbes or on the differences in ribosome of microbial cells.

Table8. Antibacterial activities of ligand and its complexes

\begin{tabular}{|c|c|c|c|c|}
\hline Compound & \multicolumn{4}{|c|}{ Diameter of inhibition zone $(\mathrm{mm})$} \\
\hline $\mathrm{HL}$ & $\begin{array}{c}\text { Bacillus Subtilis } \\
\left(\mathrm{G}^{+}\right)\end{array}$ & $\begin{array}{c}\text { Staphylococcus } \\
\text { Aureus }\left(\mathrm{G}^{+}\right)\end{array}$ & $\begin{array}{c}\text { Escherichia } \\
\text { Coli }\left(\mathrm{G}^{-}\right)\end{array}$ & $\begin{array}{c}\text { Pseudomonas } \\
\text { Aeruginosa }\left(\mathrm{G}^{-}\right)\end{array}$ \\
\hline$\left[\mathrm{Cu}(\mathrm{HL})(\mathrm{AcO})_{2}\right] \cdot \mathrm{H}_{2} \mathrm{O}$ & 13 & 12 & 11 & 14 \\
\hline$\left[\mathrm{Ni}(\mathrm{HL})(\mathrm{AcO})_{2} \mathrm{H}_{2} \mathrm{O}\right] \cdot \mathrm{H}_{2} \mathrm{O}$ & 10 & 13 & 11 & 13 \\
\hline$\left[\mathrm{Fe}(\mathrm{HL}) \mathrm{Cl}_{3}\right] \cdot \mathrm{H}_{2} \mathrm{O}$ & 9 & 15 & 13 & 13 \\
\hline$\left[\mathrm{Co}(\mathrm{HL})(\mathrm{AcO})_{2} \mathrm{H}_{2} \mathrm{O}\right] \cdot \mathrm{H}_{2} \mathrm{O}$ & 16 & 13 & 10 & 10 \\
\hline$\left[\mathrm{Zn}(\mathrm{HL})(\mathrm{AcO})_{2} \mathrm{H}_{2} \mathrm{O}\right] \cdot \mathrm{H}_{2} \mathrm{O}$ & 16 & 14 & 14 & 16 \\
\hline$\left[\mathrm{Hg}(\mathrm{HL})(\mathrm{AcO})_{2} \mathrm{H}_{2} \mathrm{O}\right] \cdot \mathrm{H}_{2} \mathrm{O}$ & 27 & 31 & 28 & 29 \\
\hline$\left[\mathrm{La}(\mathrm{HL})\left(\mathrm{NO}_{3}\right)_{3}\right] \cdot 2 \mathrm{H}_{2} \mathrm{O}$ & 12 & 12 & 13 & 10 \\
\hline$\left[\mathrm{Sm}(\mathrm{HL})(\mathrm{ClO})_{3}\right] \cdot 2 \mathrm{H}_{2} \mathrm{O}$ & 9 & 9 & 9 & 9 \\
\hline Standard:Tetracycline & 31 & 28 & 30 & 29 \\
\hline Antibacterial agent & & & & \\
\hline
\end{tabular}

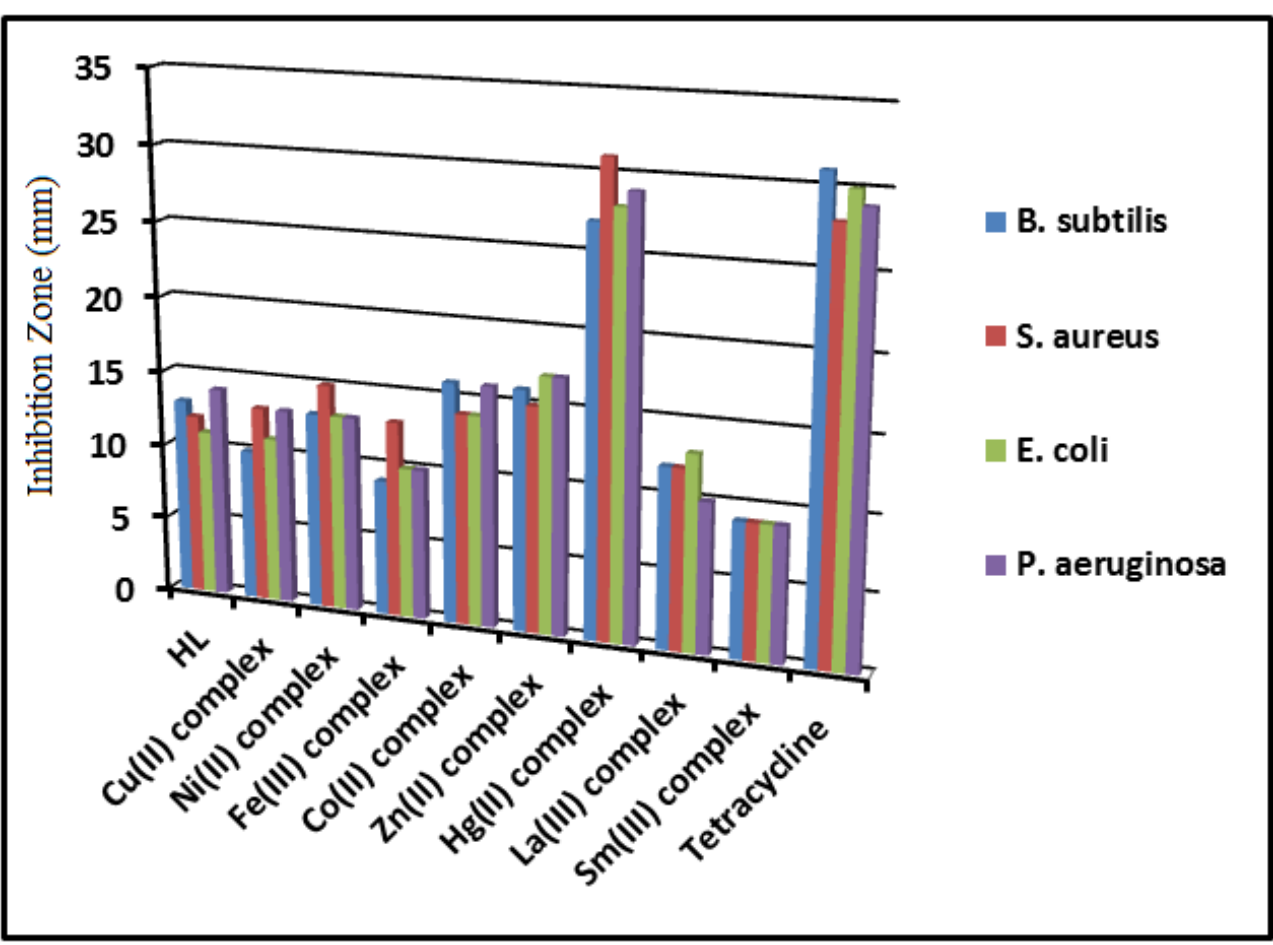

Fig6. Antibactirial activity of compounds under study

\section{CONCLUSiON}

A series of eight mononuclear complexes are synthesize and characterize by elemental analysis, TGA, spectral analysis like ${ }^{1} \mathrm{H}$ NMR, Solid Reflectance, FT-IR and Mass Spectrometry. The results support the suggested structure of metal complexes. Conductance measurements showeda non-electrolyte nature of complexes. The studies suggest the coordination of the Schiff base (HL) to metals is in its protonated form acting as tridentate NON ligand. Thermal studies indicated high stability complexes. Fluorescence studies showed that the reported ligand and its complexes can potentially serve as 
photoactive materials. The corrosion inhibition data showed that HL and its complexes are efficient corrosion inhibitors for stainless steel type 410. Furthermore, the novel complexes exhibit considerable antibacterial activity against B. subtilis, S. aureus, E. coli and P. aeruginosa, in comparison with the standard drug tetracycillin.

\section{REFERENCES}

[1] Taha ZA, AjlouniAM, Al-Hassan KA, Hijazi AK, Faiq AB.(2011). Syntheses, characterization, biological activity and fluorescence properties of bis-(salicylaldehyde)-1, 3-propylenediimine Schiff base ligand and its lanthanide complexes. SpectrochimActa, Part A.81:317-23.

[2] Abd El-Halim HF, Nour El-Dien FA, Mohamed GG, Mohamed NA. (2013). Chelating behavior, thermal studies and biocidal efficiency of tioconazole and its complexes with some transition metal ions.J ThermAnal Calorim.111:173-81.

[3] Manav N, Gandhi N, Kaushik NK. (2000). Some tribenzyltin(IV) complexes with thiohydrazides and thiodiamines. synthesis, characterization and thermal studies. J Therm Anal Calorim.61:127-34.

[4] Chaudhary A, Bansal N, Gajraj A, Singh RV. (2003). Antifertility, antibacterial, antifungal and percent disease incidence aspects of macrocyclic complexes of manganese(II). J InorgBiochem.96:393-400.

[5] Soliman MH, Mohamed GG, Mohamed EA. (2010). Metal complexes of fenoterol drug.J Therm Anal Calorim.99:639-47.

[6] Radecka-Paryzek W, Patroniak V, Lisowski J. (2005). Metal complexes of polyaza and polyoxaaza Schiff base macrocycles. CoordChem Rev, 249:2156-75.

[7] Rezaeivalaa M, Keypour H. (2014). Schiff base and non-Schiff base macrocyclic ligands and complexes incorporating the pyridine moiety - the first 50 years. CoordChem Rev.280:203-53.

[8] Andruh M. (2015). The exceptionally rich coordination chemistry generated by Schiff-base ligands derived from o-vanillin. Dalton Trans. 44:16633-53.

[9] Gupta AK, Pal R. (2015). Dehydroacetic acid based Schiff bases and their metal complexes: a review. World J Pharm Pharmacol Sci. 4:386-425.

[10] Sadeek SA, Refat MS. (2006). Preparation and characterization of Tin(II) complexes with isomeric series of Schiff bases as ligands. J Korean Chem Soc.50:107-15.

[11] Bukonjic' AM, Tomovic' DLJ, Nikolic' MV, Mijajlovic' MZ, Jevtic' VV, Ratkovic' ZR, Novakovic' SB, Bogdanovic' GA, Radojevic' ID, Maksimovic' JZ, Vasic' SM, C `omic' LR, Trifunovic' SR, Radic' GP. (2017). Antibacterial, antibiofilm and antioxidant screening of copper (II) complexes with some S-alkyl derivatives of thiosalicylic acid. Crystal structure of the binuclear copper(II)-complex withS-propyl derivative of thiosalicylic acid. J MolStruct.1128:330-7.

[12] Gandra RM, Mc Carron P, Fernandes MF, Ramos LS, Mello TP,Aor AC, Branquinha MH, McCann M, Devereux M, Santos ALS .(2017). Antifungal potential of Copper (II), Manganese (II) and Silver (I) 1, 10phenanthroline chelates against multidrug-resistant fungal species forming the Candida haemulonii complex: impact on the planktonic and biofilm lifestyles. Front Microbiol. 8:1-11.

[13] Olar R, Vlaicu ID, Chifiriuc MC, Bleotu C, Stanica N, VasileSca et, eanu G, Silvestro L, Dulea C, Badea M. (2017). Synthesis, thermal analysis and biological characterisation of some new nickel (II) complexes with unsaturated carboxylates and heterocyclic N-donor ligands.J Therm Anal Calorim.127:731-41.

[14] Zayed EM, Mohamed GG, Hindy AMM. (2015). Transition metal complexes of novel Schiff bases synthesis, spectroscopic characterization, and in vitro antimicrobial activity of complexes.J Therm Anal Calorim.120:893-903.

[15] Kalinowska M, Swiderski G, Matejczyk M, Lewandowski W. (2016). Spectroscopic,thermogravimetric and biological studies of $\mathrm{Na}(\mathrm{I}), \mathrm{Ni}(\mathrm{II})$ and $\mathrm{Zn}$ (II) complexes of quercetin. JThermAnalCalorim.126:141-8.

[16] Dhahagani K, Kumar SM, Chakkaravarthi G, Anitha K, Rajesh J,Ramu A, Rajagopal G. (2014). Synthesis and spectral characterization of Schiff base complexes of $\mathrm{Cu}(\mathrm{II}), \mathrm{Co}(\mathrm{II}), \mathrm{Zn}(\mathrm{II})$ and $\mathrm{VO}$ (IV) containing 4(4-aminophenyl) morpholine derivatives: antimicrobial evaluation and anticancer studies. SpectrochimActa, Part A. 87:94-117.

[17] Prabhakaran R, Geetha A, Thilagavathi M, Karvembu R, Krishnan V, Bertagnolli H, Natarajan K. (2004). Synthesis, characterization, EXAFS investigation and antibacterial activities of new ruthenium ) III) complexes containing tetradentate Schiff base. J InorgBiochem. 98:2131-40.

[18] Uddin MN, Abdus Salam Md, Sultana J. (2015). Pb(II) complexes of Schiff bases derived from benzoylhydrazine as the antibacterial agents. Mod Chem. 3:7-14.

[19] Zhou X, Shao L, Jin Z, Liu J-B, Dai H, Fang J-X. (2007). Synthesis and antitumor activity evaluation of some Schiff bases derived from 2-aminothiazole derivatives. Heteroatom Chem. 18:55-9. 
[20] Saadeh HA, AbuShaireh EA, Mosleh IM, Al-Bakri AG, Mubarak MS. (2012). Synthesis, characterization and biological activity of Schiff bases derived from metronidazole. Med Chem Res. 21: 2969-74.

[21] Parrey IR, Hashmi AA. (2015). Synthesis of Schiff base complexes ofMn(II) and Co(II) and their catalytic oxidation towards olefinsand alcohols. Can Chem Trans. 3:65-71.

[22] Balasubramanian KP, Karvembu R, Prabhakaran R, Chinnusamy V, Natarajan K. (2007). Synthesis, spectral, catalytic and antimicrobial studies of $\mathrm{PPh} 3 / \mathrm{AsPh} 3$ complexes of $\mathrm{Ru}(\mathrm{II})$ with dibasic tridentate $\mathrm{O}$, N, S donor ligands. SpectrochimActa, Part A. 68:50-4.

[23] Ali OAM. (2014). Palladium(II) and zinc(II) complexes of neutral [N2O2] donor Schiff bases derived from furfuraldehyde: synthesis, characterization, fluorescence and corrosion inhibitors of ligands.SpectrochimActa, Part A. 132:52-60.

[24] Bhkahk CK, Hadi JS. (2015). New unsymmetrical Schiff base as inhibitor of carbon steel corrosion and antibacterial activity. Res J Chem Sci. 5:64-70.

[25] Fouda AS, Ibrahim AA,El-behairy WT. (2014). Thiophene derivatives as corrosion inhibitors for carbon steel in hydrochloric acid solutions Der PharmaChemica, 6(5):144-157.

[26] ASTM, Standard Practice for Laboratory Immersion Corrosion Testing of Metals, G 31-72, ASTM, Philadelphia, PA (1990) 401.

[27] Salman Y, Barlas FB, Yavuz M, Kaya K, Timur S,Telli FÇ, (2018). Synthesis, characterization and biological application of dinuclearCu(II(complexes of Schiff base ligands of galactochloralose and $\alpha$ chloralose.InorgChimActa.483:98-105.

[28] Mounika K, Anupama B, Pragathi J, Gyanakumari C. (2010). Synthesis, Characterization and Biological Activity of a Schiff Base Derivedfrom 3-Ethoxy Salicylaldehyde and 2-Amino Benzoic acid and its TransitionMetal Complexes. J. Sci. Res. 2:513-24.

[29] Byun JC, Mun DH, Park KM, (2014). Synthesis and Characterization of Compartmental Macrocyclic Binuclear Copper(II) Complex with BidentatePerchlorato Ligand. Bull. Korean Chem. Soc. 35:269-72.

[30] Nakamoto K. (1986). Infrared and Raman Spectra of Inorganic and Coordination Compounds, Wiley, New York, pp 227, $256-257$.

[31] Taha ZA, Ajlouni AM, Al Momani W. (2012). Structural, luminescence and biological studies of trivalent lanthanide complexes with N,N'-bis(2-hydroxynaphthylmethylidene)-1,3-propanediamine Schiff base ligand Journal of Luminescence 132:2832-41.

[32] Calu L, Badea M, Korošin NČ, Chifiriuc MC, Bleotu C, Stanică N, Silvestro L, Maurer M, Olar R.(2018). Spectral, thermal and biological characterization of complexeswith a Schiff basebearing triazole moiety as potential antimicrobialspecies. J. Therm. Anal. Calorim.134:1839-50.

[33] AranhaPE, dos Santos MP, RomeraS,Dockal ER. (2007). "Synthesis, characterization, and spectroscopic studies of tetradentate Schiff base chromium(III) complexes," Polyhedron.26:1373-82.

[34] Abd El-Wahab ZH, Mashaly MM, Salman AA, El-ShetaryBA,Faheim AA. (2004).Co(II), Ce(III) and UO2(VI) Bis-Salicylatothiosemicarbazide Complexes: Binary and Ternary Complexes, Thermal Studies and Antimicrobial Activity. SpectrochimActa, Part A. 60:2861-73.

[35] Abu-Hussen AAA, Linert W.(2009).Redox, thermodynamic and spectroscopic of some transition metal complexes containing heterocyclic Schiff base ligands.SpectrochimActa, Part A. 74:214-23.

[36] Mohamed GG, Omar MM, Hindy AMM. (2005). Synthesis, characterization and biological activity of some transition metals with Schiff base derived from 2-thiophene carboxaldehyde and aminobenzoic acid.SpectrochimActa, Part A. 62:1140-50.

[37] Zayed MA, Nour El-Dien FA, Mohamed GG, El-Gamel NEA. (2004). Structure investigation, spectral, thermal, X-ray and mass characterization of piroxicam and its metal complexes. SpectrochimActa, Part A. 60:2843-52.

[38] Mohamed GG, Abd El-Wahab ZH (2005). Mixed ligand complexes of bis(phenylimine) Schiff base ligands incorporating pyridinium moiety Synthesis, characterization and antibacterial activity. Spectrochim Acta, Part A. 61:1059-68.

[39] Ali OAM (2014). Synthesis, spectroscopic, fluorescence properties and biological evaluation of novel Pd (II) and Cd (II) complexes of NOON tetradentate Schiff bases.SpectrochimActa, Part A. 21:188-95.

[40] Refat MS, El-Metwaly NM. (2011). Spectroscopic and fluorescence studies on Mn(II), Co(II), Ni(II) and $\mathrm{Cu}(\mathrm{II})$ complexes with NO donor fluorescence dyes. SpectrochimActa, Part A. 81:215-27.

[41] Massoud AA, Hefnawy A, Langer V, Khatab MA, Öhrstrom L,Abu-Youssef MAM. (2009).Synthesis, Xray structure and anti-corrosion activity of two new silver(I) pyrazino complexes. Polyhedron 28:27942802. 
Spectroscopic, Thermal, Fluorescence Studies and Antibacterial Activity of Some Transition Metals with Schiff Base 2-[(2-Furylmethylene) Amino] Benzoic Acid

[42] Dharmaraj N, Viswanathamurthi P, Nataragan K (2001).Ruthenium(II) complexes containing bidentate Schiff bases and their antifungal activity.

[43] J. Transition Met. Chem. 26:105-09.

Citation: Omyma Ahmed Moustafa Ali, et.al, "Spectroscopic, Thermal, Fluorescence Studies and Antibacterial Activity of Some Transition Metals with Schiff Base 2-[(2-Furylmethylene) Amino] Benzoic Acid”, International Journal of Advanced Research in Chemical Science, vol. 6, no. 10, p. 7-21, 2019. DOI: http://dx.doi.org/10.20431/2349-0403.0610002

Copyright: (C) 2019 Authors. This is an open-access article distributed under the terms of the Creative Commons Attribution License, which permits unrestricted use, distribution, and reproduction in any medium, provided the original author and source are credited. 